United States Department of Energy

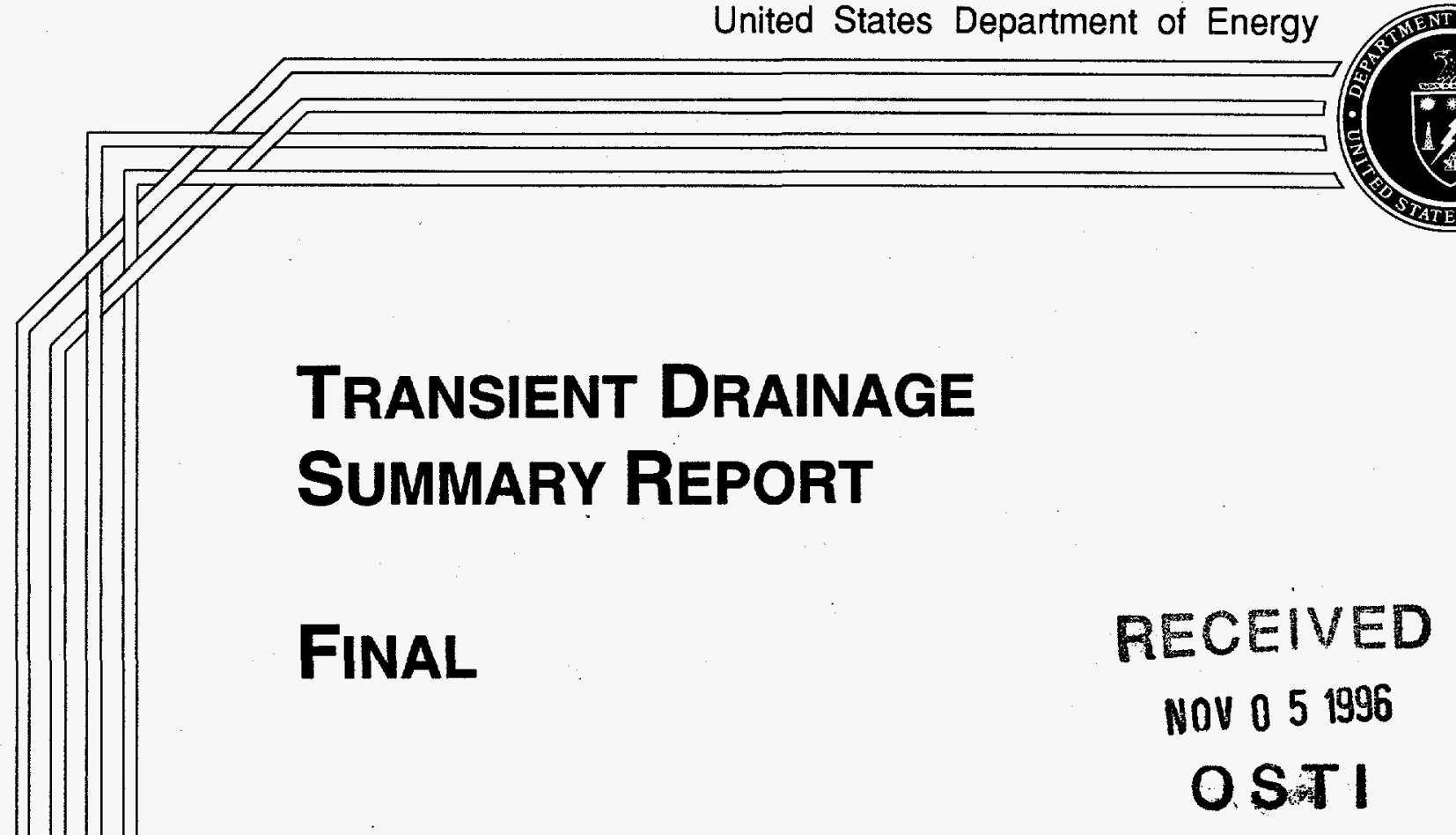

September 1996 


\section{INTENDED FOR PUBLIC RELEASE}

This report has been reproduced from the best available copy. Available in paper copy and microfiche

Number of pages in this report: 78

DOE and DOE contractors can obtain copies of this report from:

Office of Scientific and Technical Information

P.O. Box 62

Oak Ridge, TN 37831

(615) 576-8401

This report is publicly available from:

National Technical Information Service

Department of Commerce

5285 Port Royal Road

Springfield, VA 22161

(703) 487-4650 


\title{
TRANSIENT DRAINAGE SUMMARY REPORT
}

\section{September 1996}

\author{
Prepared for \\ U.S. Department of Energy \\ Environmental Restoration Division \\ UMTRA Project Team \\ Albuquerque, New Mexico \\ Prepared by \\ Jacobs Engineering Group Inc. \\ Albuquerque, New Mexico
}

\section{DISCLAIMER}

\begin{abstract}
This report was prepared as an account of work sponsored by an agency of the United States Government. Neither the United States Government nor any agency thereof, nor any of their employees, makes any warranty, express or implied, or assumes any legal liability or responsibility for the accuracy, completeness, or usefulness of any information, apparatus, product, or process disclosed, or represents that its use would not infringe privately owned rights. Reference herein to any specific commercial product, process, or service by trade name, trademark, manufacturer, or otherwise does not necessarily constitute or imply its endorsement, recommendation, or favoring by the United States Government or any agency thereof. The views and opinions of authors expressed herein do not necessarily state or reflect those of the United States Government or any agency thereof.
\end{abstract}




\section{DISCLAIMER}

Portions of this document may be illegible in electronic image products. Images are produced from the best available original document. 


\section{EXECUTIVE SUMMARY}

This report summarizes the history of transient drainage issues and analyses on the Uranium Mill Tailings Remedial Action (UMTRA) Project. Analysis indicates that transient drainage will not be a major source of ground water contamination at UMTRA Project disposal sites. The significant event that brought transient issues to the forefront was the introduction of proposed UMTRA ground water standards in 1987.

Before the proposed ground water standards were introduced, transient drainage was considered a geotechnical problem and was analyzed in terms of consolidation or settlement. Primary concerns were the effect of released water on slope stability, and whether seepage from the sideslopes would transport radioactive material to the ground surface.

The ground water standards proposed in 1987 provided quantitative water quality standards in the form of maximum concentration limits. To meet these limits or to apply supplemental standards, cell design focused on limiting all water (including transient drainage) passing through the cell foundation.

In response to the proposed standards the UMTRA Project provided additional transient drainage analyses, where needed, to support the ground water protection strategies. Design and construction of the UMTRA Project disposal cells were changed as needed to minimize the quantity of water in the tailings during and after stabilization operations. These changes included relocating and dewatering tailings, limiting water use for compaction and dust control, encouraging the use of surfactants for dust control, collecting and diverting precipitation, and decreasing infiltration through the disposal cell covers.

Section 4.0 of this report summarizes information for each disposal site. The summaries include a conceptual drawing of the cell location and the underlying hydrogeologic system; notes detail disposal site design and construction, the ground water protection strategy, and transient drainage modeling. The information provided shows that the impact of transient drainage on ground water protection strategies has been minimal because careful siting of the disposal cells made use of favorable environmental factors. These factors, such as poor ambient water quality, geological isolation, low yield aquifers, and favorable hydrogeologic conditions, as well as cell design, have minimized contamination of ground water. 


\section{TABLE OF CONTENTS}

Section

Page

1.0 INTRODUCTION ......................................................................................... $1-1$

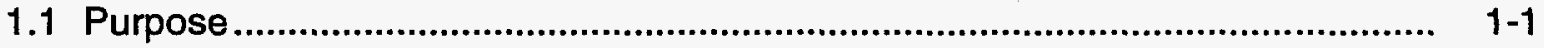

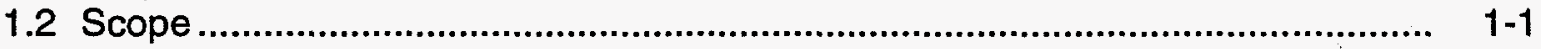

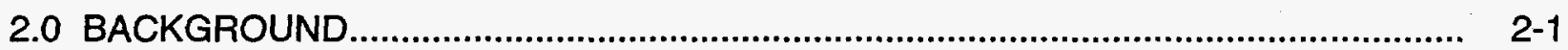

3.0 PROJECT HISTORY ...............................................................................

4.0 DISPOSAL CELL INFORMATION....................................................................

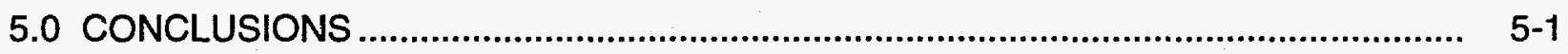

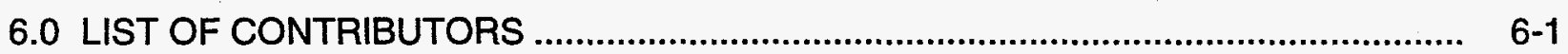

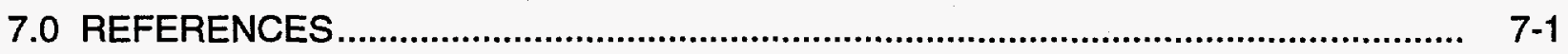




\section{LIST OF FIGURES}

\section{Figure}

Page

1.1 Representation of specific yield of sand

1.2 Characteristic curves relating hydraulic conductivity and moisture content to pressure head for a naturally occurring sand.

1.3 Hydromechanical analogy for load-sharing and consolidation

2.1 Water balance

2.2. Sources of transient drainage

3.1 UMTRA Project site timeline

4.1 Hydrogeologic cross section, Ambrosia Lake, New Mexico, site

4.2 Hydrogeologic cross section, Burrell site, Canonsburg, Pennsylvania .

4.3 Hydrogeologic cross section, Canonsburg, Pennsylvania, site.

4.4 Hydrogeologic cross section, Bodo Canyon site, Durango, Colorado..

4.5 Hydrogeologic cross section, Falls City, Texas, site

Hydrogeologic cross section, Cheney disposal cell, Grand Junction,

Colorado, site

4.7 Hydrogeologic cross section, Green River, Utah, site.

4.8 Hydrogeologic cross section, Gunnison, Colorado, site

4.9 Hydrogeologic cross section, Collins Ranch site, Lakeview, Oregon...................... 4-19

4.10 Hydrogeologic cross section, Lowman, Idaho, site

4.11 Structural cross section, Maybell, Colorado, site

4.12 Hydrogeologic cross section, Mexican Hat, Utah, site

4.13 Hydrogeologic cross section, Naturita, Colorado, site

4.14 Hydrogeologic cross section, Estes Gulch disposal site, Rifle, Colorado

4.15 Cross section, Clive disposal site, Salt Lake City, Utah

4.16 Hydrogeologic cross section, Shiprock, New Mexico, site

4.17 Hydrogeologic cross section, Burro Canyon disposal site,

Slick Rock, Colorado

4.18 Hydrogeologic cross section, Spook, Wyoming, site 


\section{LIST OF ACRONYMS}

\section{Acronym}

$A C L$

EPA

HELP

LTSP

$\mathrm{MCL}$

NRC

SIP

SOS

TAD

UMTRA

UMTRCA

VP

\section{Definition}

alternate concentration limit

U.S. Environmental Protection Agency

Hydrologic Evaluation of Landfill Performance (Computer Model)

long-term surveillance plan

maximum concentration limit

U.S. Nuclear Regulatory Commission

stabilized in place

stabilized on site

technical approach document

Uranium Mill Tailings Remedial Action

Uranium Mill Tailings Radiation Control Act

vicinity property 


\section{CHANGE HISTORY}

\begin{tabular}{cll}
\hline Document version & Date & \multicolumn{1}{c}{ Pages/comments } \\
\hline Rev. 0, Ver. 1 & $2 / 26 / 95$ & $\begin{array}{l}\text { Initial version. Compiled reference } \\
\text { list of RAPs, SOWPs and LTSPs. } \\
\text { Waiting for remainder of figures. } \\
\text { Retain double-spacing for internal } \\
\text { draft. }\end{array}$ \\
\hline Rev. 1, Ver. 1 & $3 / 20 / 96$ & $\begin{array}{l}\text { Author and client review comments } \\
\text { incorporated, client review. }\end{array}$ \\
\hline Rev. 1, Ver. 2 & $3 / 20 / 96$ & $\begin{array}{l}\text { Printed on internal draft paper for } \\
\text { delivery to client for review. }\end{array}$ \\
\hline Rev. 2, Ver. 1 & $4 / 29 / 96$ & $\begin{array}{l}\text { Edited; comments incorporated in } \\
\text { response to client comments. }\end{array}$ \\
\hline Rev. 2, Ver. 2 & $5 / 2 / 96$ & $\begin{array}{l}\text { Author review comments } \\
\text { incorporated. }\end{array}$ \\
\hline Rev. 2, Ver. 3 & $6 / 10 / 96$ & NRC review comments incorporated. \\
\hline Rev. 2, Ver. 4 & $6 / 24 / 96$ & Prepared for reproduction. \\
\hline Rev. 2, Ver. 5 & $9 / 20 / 96$ & $\begin{array}{l}\text { Additional client comments } \\
\text { incorporated. }\end{array}$ \\
\hline
\end{tabular}




\subsection{INTRODUCTION}

$1.1 \quad$ PURPOSE

This report summarizes the history of transient drainage issues on the Uranium Mill Tailings Remedial Action (UMTRA) Project. It defines and describes the UMTRA Project disposal cell transient drainage process and chronicles UMTRA Project treatment of the transient drainage phenomenon. Section 4.0 includes a conceptual cross section of each UMTRA Project disposal site and summarizes design and construction information, the ground water protection strategy, and the potential for transient drainage.

\subsection{SCOPE}

The scope of this report is limited to transient drainage at UMTRA Project disposal cells, providing a historical overview rather than a technical summary of the site-specific methods used to evaluate transient drainage. References specific to the sites are included to allow a more in-depth study of the transient drainage phenomenon and how transient drainage was/is being analyzed during the UMTRA Project.

\section{$1.3 \quad$ TRANSIENT DRAINAGE DEFINED}

Because this report focuses on transient drainage, transient drainage must be defined. Transient drainage as a concept is best explained in terms of aquifer properties. Specific yield is the volume of water that a saturated, unconfined, porous material will give up when drained by gravity. The part of the water that is not removed by gravity drainage and is held against the force of gravity by molecular attraction and capillarity is called specific retention. Figure 1.1 illustrates these quantities. The quantity of transient drainage from a saturated porous material is equal to the specific yield.

In unsaturated material, transient drainage is more difficult to quantify because the curve depicting the specific moisture capacity versus pressure of the material must be developed and the current location of the saturation level of the material on this curve must be determined. Figure 1.2 illustrates the relationship of moisture content to pressure head in an unsaturated soil.

Subjecting the soil material to additional compressive loading complicates quantifying transient drainage. In disposal cells, additional loading occurs as the weight of additional tailings are applied on top of an existing tailings pile or as cover materials are placed over the cell. In a saturated material, the weight of this additional material decreases the pore space of the underlying tailings, applying pressure to water in the pore spaces and changing the capacity of the material to retain or yield water. This phenomenon is referred to as consolidation. It results in settlement of the disposal cell and increases the quantity of transient drainage. Figure 1.3 illustrates this concept. The 


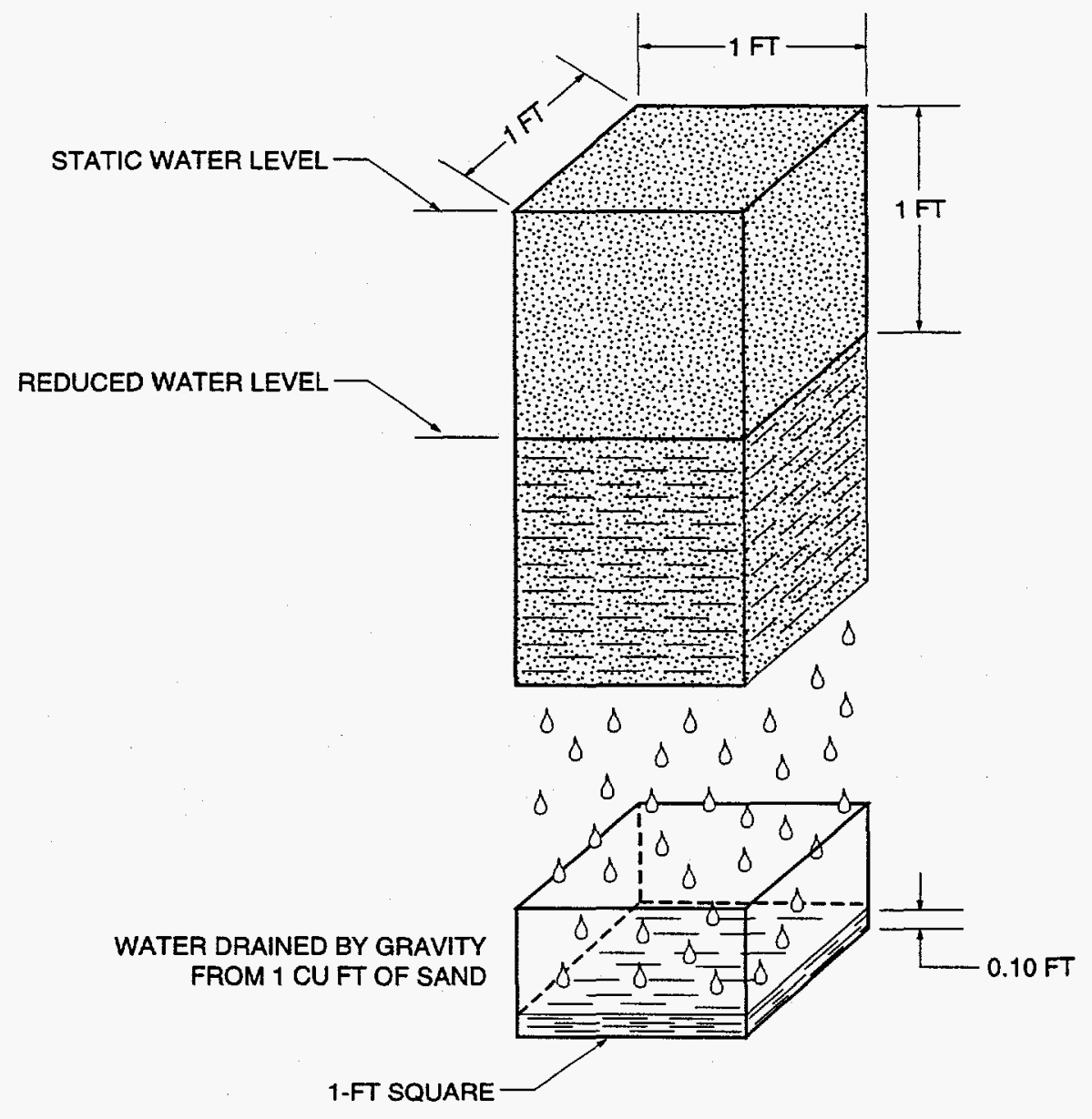

NOTE: SPECIFIC YIELD OF SAND CAN BE VISUALIZED FROM THIS DIAGRAM. ITS VALUE HERE IS 0.10 CU FT PER CU FT OF AQUIFER MATERIAL.

FIGURE 1.1

REPRESENTATION OF SPECIFIC YIELD OF SAND 


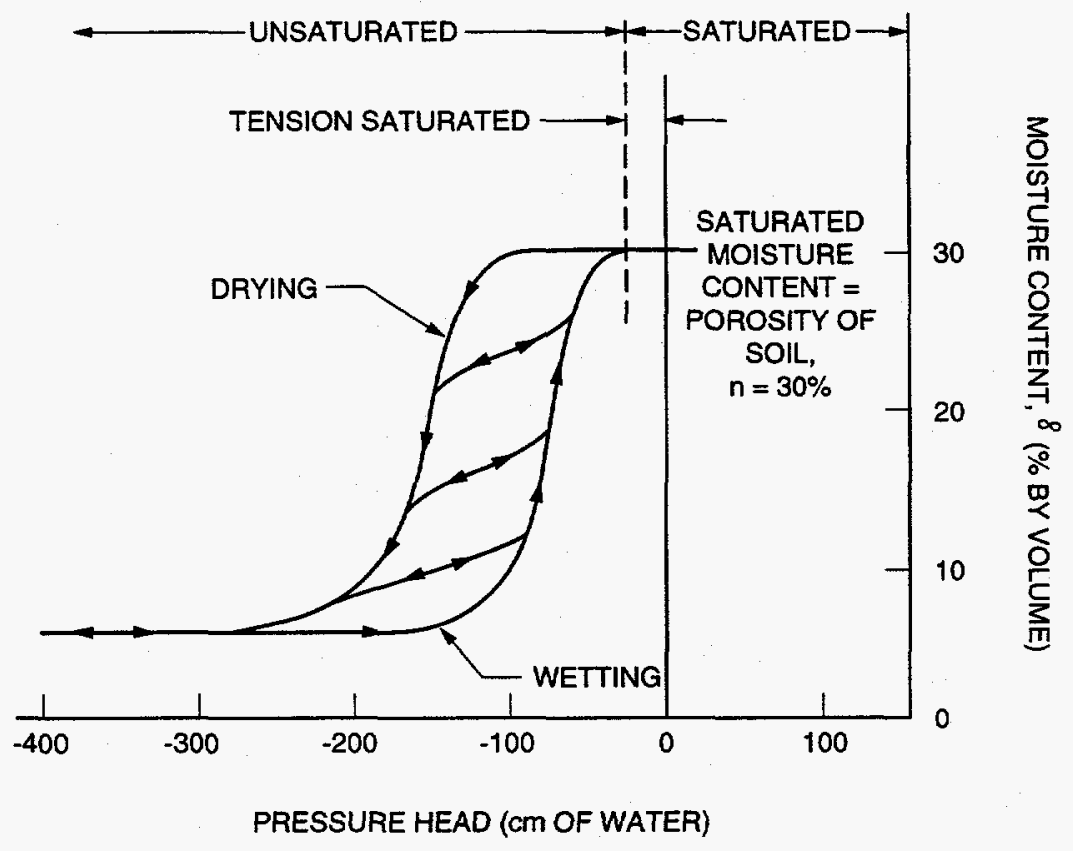

FIGURE 1.2

CHARACTERISTIC CURVES RELATING MOISTURE CONTENT TO PRESSURE HEAD FOR A NATURALLY OCCURRING SAND 


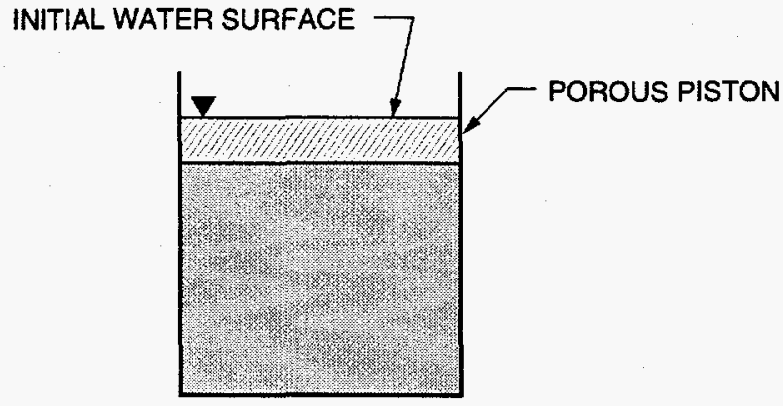

a. Physical example.

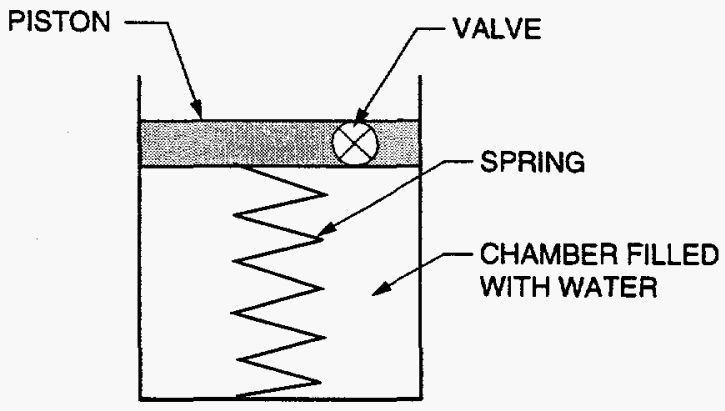

b. Hydromechanical analog; initial condition.

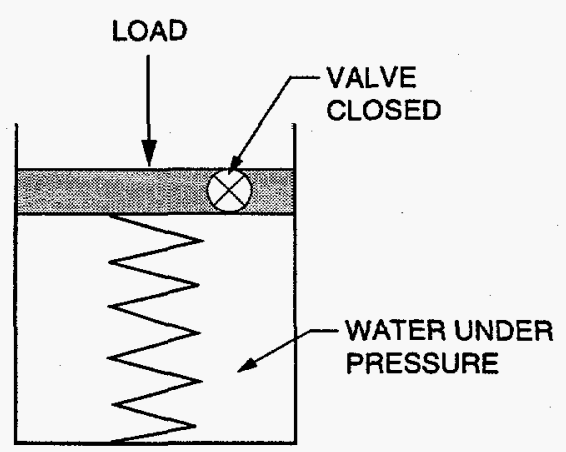

c. Load applied with valve closed.

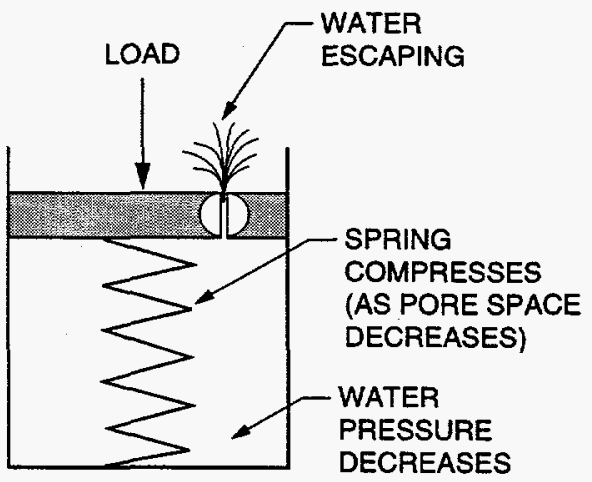

d. Piston moves as water escapes.

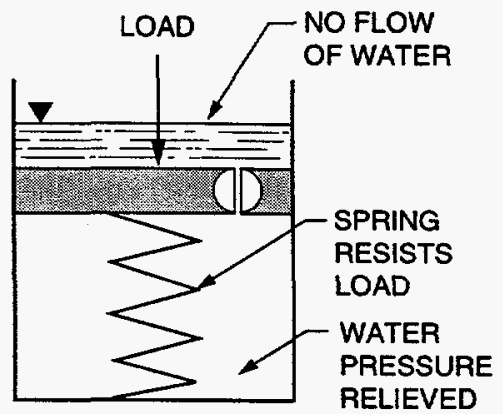

e. Equilibrium with no further flow.

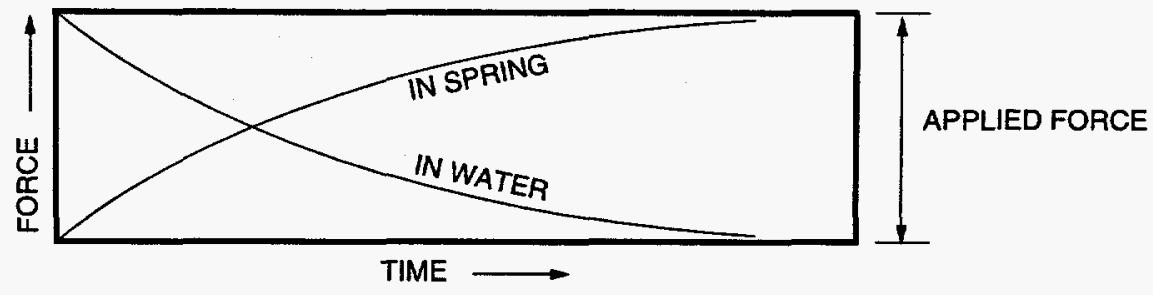

f. Gradual transfer of load. 
consolidation phenomenon is complicated further by the heterogeneous nature of the tailings. The layers and lenses of fine-grained slimes interspersed throughout the sand tailings, each with very different consolidation properties, make it difficult to analyze a disposal cell as a single unit. 


\subsection{BACKGROUND}

Section 1.0 defines transient drainage in terms of the hydrogeologic properties of soils. It is important to recognize that as the word "transient" implies, this drainage is a temporary condition that occurs over a period of time. It is initiated by a change in the initial steady-state conditions and ends when new steady-state conditions are attained. At UMTRA Project disposal sites, the initial condition is that which exists prior to any stabilization of the tailings. Once tailings are placed or the load on existing tailings is changed, transient drainage begins. Transient drainage ends at UMTRA disposal cells after the disposal cell is closed, excess water drains out, and a water balance (steady-state condition) is achieved.

Only the water already present in the tailings when the radon/infiltration barrier component of the cover is completely placed constitutes the transient drainage. Water infiltrating through the cover will mingle with the water already in the tailings and the combined flow will leave the cell. However, the infiltration after completion of the cover is not part of transient drainage because it is a function of the cover design, which controls the steady-state drainage condition due to the fact that the radon barrier component has the lowest hydraulic conductivity.

As Figure 2.1 illustrates, the cover infiltration establishes the steady-state condition of flow through the disposal cell. Infiltration through the cover can be decreased by increasing runoff, drainage, and evapotranspiration; various design components have been developed to provide these conditions. Vegetated topslopes have been included to increase evapotranspiration where runoff and drainage are not as rapid because of flatter slopes. Bentonite amendment of the radon/infiltration barrier and the use of geosynthetic clay liners have promoted drainage and minimized infiltration. High permeability bedding/drain layers also have promoted precipitation drainage. These UMTRA Project design practices have been developed to balance the requirements for minimizing infiltration with the requirements for preventing physical exposure of tailings as a result of catastrophic failure from earthquakes, wind and water erosion, and human or animal intrusion.

As shown in Figure 2.2, the water included in transient drainage enters a disposal cell in several ways. Some moisture was introduced in the milling process if tailings were transported and deposited by a hydraulic placement system. Prior to remedial action, additional water was introduced by infiltration of precipitation, dust control at some locations, and irrigation at a few sites where grass was planted in an attempt to stabilize the tailings in place. During remedial action, limited amounts of water were introduced into the tailings to increase compaction density and to provide dust control. Water also infiltrated from precipitation, prior to cover placement.

Transient drainage from UMTRA Project disposal cells into the underlying soil and bedrock deposits has been considered at each site. Though the quantity of water is limited, transient drainage is contaminated water, and careful evaluation is needed to determine its effect on ground water quality.

The quantity of transient drainage and the time required to reach steady-state conditions varies from site to site on the UMTRA Project. Several factors cause these variations. One 


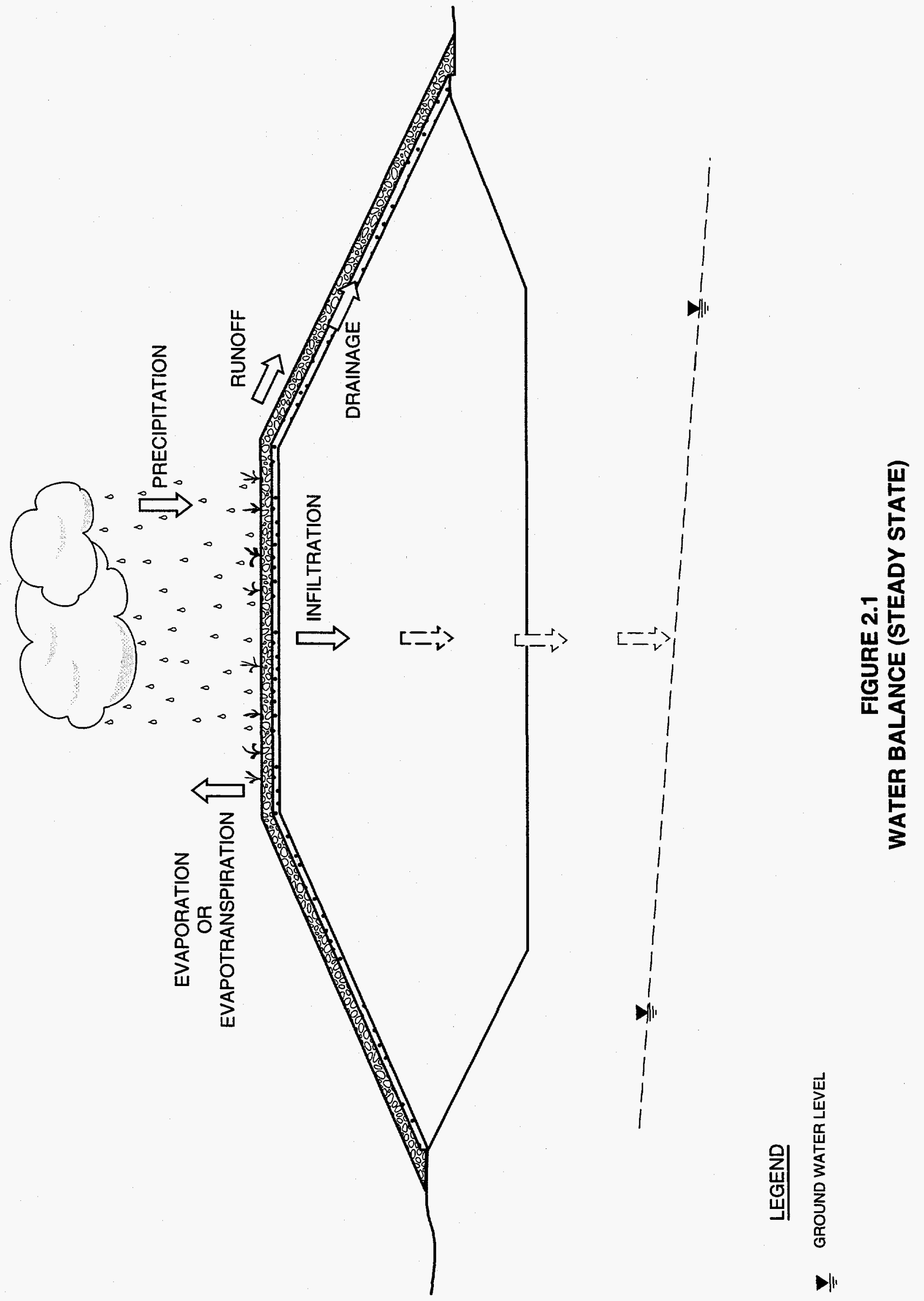


INFILTRATION

FROM RAINFALL OR SNOWMELT

PRIOR TO

COVER PLACEMENT

COMPACTION WATER

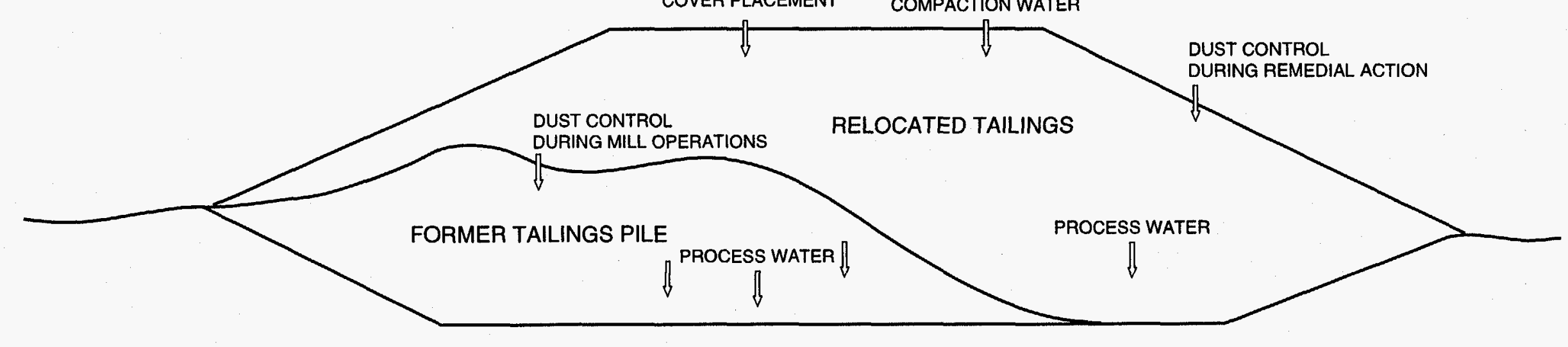

FIGURE 2.2

SOURCES OF TRANSIENT DRAINAGE 
of the major contributors to transient drainage differences between sites is cell construction. That is, whether the disposal cell was stabilized in place (SIP) or constructed of tailings moved from the processing site to a new disposal cell location (relocation). Intermediate to these two scenarios, tailings may be deposited into a new location on the processing site, that is, stabilized on site (SOS).

Transient drainage quantities typically are higher at SIP sites than at relocation sites because the SIP site tailings frequently retain more moisture as a result of hydraulic placement during the milling process. Relocation of tailings allows some drainage and evaporation of this water and also some mixing of drier tailings with wetter tailings. However, some relocated tailings were still very wet due to the processing sites being low-lying areas next to rivers.

At SIP and SOS sites, where the cell footprint is located over an existing tailings pile, transient drainage from the disposal cell area began when the tailings were first deposited after processing. However, transient drainage specific to the UMTRA Project begins when stabilization efforts initiate placement of material over the old tailings pile, and is considered separately from the transient drainage caused by processing operations. Though these flows are considered separately, they cannot be distinguished from each other by field testing. Only computer modeling of past process conditions and adding the post-remedial action changes can analytically separate pre-UMTRA Project transient drainage from transient drainage caused by remedial action. At sites where tailings are relocated, the transient drainage process begins when placement of the relocated tailings starts and there is no complication from previous transient drainage.

The particle size of the tailings, coupled with the density at which they are placed, also affects the amount of drainable water in the tailings. All but a small amount of water will drain out of sand tailings, through either saturated or unsaturated flow, because sands have a relatively high specific yield. Additionally, sand-sized tailings particles drain water fairly rapidly because of a higher permeability. Therefore, initial transient drainage quantities may be large, but sand tailings that have drained over a long period of time may contribute little to future transient drainage.

Fine-grained tailings, or slimes, have a lower specific yield (and a correspondingly higher specific retention) and water typically drains only as a result of saturated flow and consolidation. Thus the quantity of transient drainage from tailings with high slime content may be relatively low, but the time required for transient drainage to occur may be much longer.

The amount of sands and slimes in a tailings pile varies from site to site. Some locations have entirely sand tailings, others have large proportions of fines. The configuration and location of the slimes within the pile also can affect the quantity of and time period for transient drainage. For example, a large thickness of slimes takes longer to drain than the same volume of slimes configured as a thinner layer over a larger area. A layer of slimes below a layer of sands at a SIP site may have slowed transient drainage from the sands prior to remedial action, resulting in an increased quantity of postremediation transient drainage, as well as a long transient drainage period. In the case of relocated tailings, measures can be taken either to dry the slimes or to mix them with coarser material to minimize transient drainage-related problems.

The process of stabilization further affects transient drainage. Consolidation occurs when windblown materials, materials washed away by precipitation, materials from vicinity properties (VP), and cover materials are placed on top of a SIP pile, decreasing the void space and 
The process of stabilization further affects transient drainage. Consolidation occurs when windblown materials, materials washed away by precipitation, materials from vicinity properties (VP), and cover materials are placed on top of a SIP pile, decreasing the void space and forcing out additional water from the tailings, increasing the amount of transient drainage. Designs that decrease the footprint of the cells at SIP sites also result in an increased thickness, and contribute to increased transient drainage. To a lesser extent, consolidation also occurs as tailings are placed in a series of layers for relocated disposal cell construction and cover materials are added on top.

Transient drainage moves as both saturated and unsaturated flow. The equations used to evaluate saturated flow offer closed form solutions and were developed long ago. The analysis is relatively easy to perform and requires only a few, well-defined parameters that are easy to measure in a laboratory. The differential equations for describing unsaturated flow do not have closed form solutions, so approximate methods must be employed, most commonly finite element and finite difference methods. Solutions to these numerical methods require many iterations of the equations and were developed only with the widespread use of computers. These methods have been applied to unsaturated flow analysis only relatively recently and the parameters needed for analysis are much more difficult to obtain than those for saturated analyses.

A coupled saturated and unsaturated flow analysis is needed to fully examine the transient drainage process and can be performed only using numerical analysis methods. Finite element computer codes provide a coupled analysis and in recent years have been used to model the transient drainage at selected UMTRA Project disposal cells. Modeling results have been used to predict the length of time required for transient drainage to cease and to reach steady-state conditions. By examining transient drainage flow out of the disposal cells and into the underlying hydrogeologic system over time, the impact of this drainage on the ground water can be developed. Then a ground water protection strategy can be advanced that considers transient drainage as well as the steady-state condition. In terms of cell performance monitoring, transient drainage analysis can help avert false interpretation of cell failure by predicting the time required for a transient drainage pulse to flow past monitor wells located immediately adjacent to the disposal cell, especially on the downgradient edge. 


\subsection{PROJECT HISTORY}

The Uranium Mill Tailings Radiation Control Act (UMTRCA) was passed in 1978. In 1981, U.S. Environmental Protection Agency (EPA) developed draft standards for surface remediation. At the time these standards were drafted, the EPA and others involved with the mill tailings thought the tailings were relatively dry. The tailings had been sitting in piles for many years and in the early 1980s, the water in them was thought to have drained from all but those adjacent to surface water. In 1983 the U.S. Nuclear Regulatory Commission (NRC) addressed the control of seepage from mill tailings and provided guidance on seepage analysis. Only saturated flow was included in the NRC analysis methods.

Soon after the draft standards for surface remediation were issued in 1981, UMTRA Project disposal cell design efforts began. Designs were completed for several sites and remedial action started in 1982. Remedial action at the first UMTRA Project site, Canonsburg, Pennsylvania, was completed in 1985. Remedial action began at Shiprock, New Mexico, in 1984; at Salt Lake City, Utah, in 1984; at Tuba City, Arizona, in 1986; at Lakeview, Oregon, in 1986; and at the Durango, Colorado, disposal site in October 1987. Protection from the emanation of radon and permanent encapsulation of the radioactive waste materials were the primary concerns of these designs. Consolidation was evaluated only as a concern for settlement and cover cracking. At the time, the standards contained no criteria for the limitation of surface water infiltration. The UMTRA technical approach document (TAD) was developed in 1986 to provide design guidelines and a systematic approach to UMTRA Project disposal cell design [39].

The Hydrologic Evaluation of Landfill Performance (HELP) model, developed by the EPA in 1983, was used to examine infiltration through the cover at Canonsburg that same year. This model examines one-dimensional transient flow, but is mathematically limited in its approach. In this case, it was used to verity that there would be no bathtub effect in the disposal cell. The use of the HELP model to examine infiltration through the covers of UMTRA cells became routine to look at this effect.

In September 1987 the EPA proposed new regulations for ground water standards. In the period between the initial standards (1983) and the new, qualitative standards for ground water (1987), eight UMTRA disposal cells were designed: Canonsburg, Burrell, Salt Lake City, Shiprock, Tuba City, Lakeview, Maybell, and Durango (Figure 3.1). The design process had been started at all remaining UMTRA Project sites. Plans were nearly complete at Rifle, Naturita, Mexican Hat, Riverton, and Ambrosia Lake. With the new ground water protection strategy requirements for each site, attention focused on infiltration and on other water sources that could affect the ground water, including transient drainage.

In February 1988, a meeting of scientists and engineers convened to discuss the impact of the new standards on the disposal of uranium mill tailings. Infiltration through the cover 
This page intentionally left blank. 


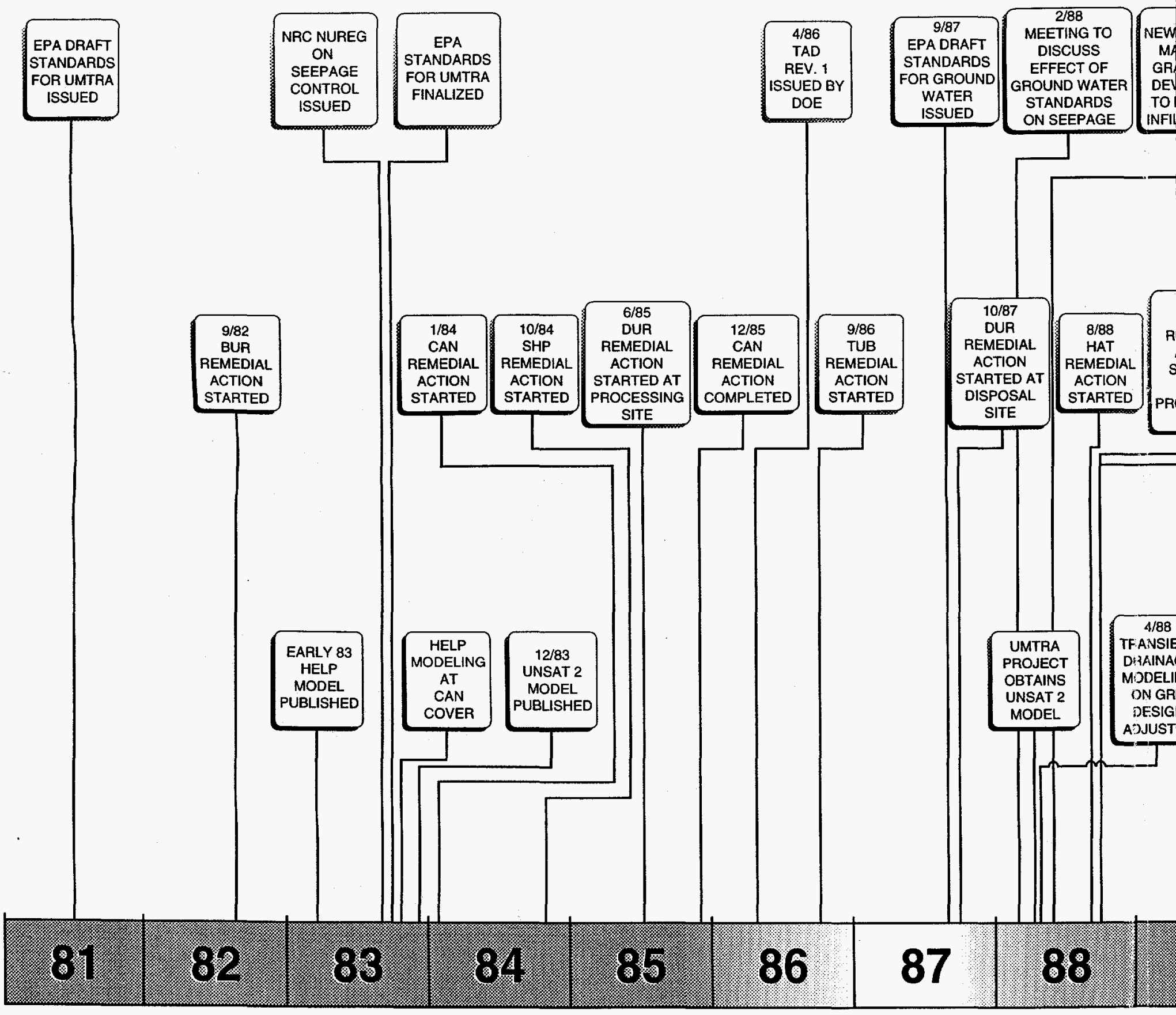


was a major topic, as was transient drainage. Analysis methods were discussed, as were methods to minimize the quantity of contaminated water reaching the water table.

This meeting in the wake of the new proposed ground water standards prompted an evaluation of the UMTRA Project disposal cell design process to determine which design features and construction controls could be used to minimize problems associated with seepage and transient drainage. It was concluded that the longevity requirements and those minimizing the use of active maintenance precluded the use of liner and leachate collection systems, which typically incorporate geosynthetics and pumping systems. It was determined that relocation and dewatering of tailings, limiting construction water, and collecting and diverting precipitation could be used to minimize transient drainage and that limiting infiltration through the cover would be the most effective way of minimizing long-term seepage.

At this time, construction water was first recognized as a contributor to transient drainage. During construction of the Green River disposal cell in 1988, the trend of using large amounts of construction water to control dust was reversed. The water truck spray bars were modified to produce a mist, reducing water application for dust control. Surfactants were added to Project dust control specifications. Specifications also were changed to require tailings compaction at lower water content with more stringent quality control to ensure compliance. Other construction techniques, such as the use of winter covers, were instituted to further prevent water from entering the incomplete cells between construction seasons.

Shortly after the new design features were implemented a situation developed that showed the importance of implementing these changes properly. The new design features and construction controls were included in the design documents for the Durango site. A lowpermeability temporary cover was placed during the 1987-1988 winter shutdown to facilitate runoff and minimize infiltration from precipitation. However, the winter cover was not removed or ripped before additional tailings were emplaced during the subsequent construction season and frequent applications of dust-control water were required to meet stringent Project dustcontrol limitations. The result was that the unsaturated flow from infiltration of that year's frequent rainfall and from construction water through the sandy tailings accumulated on top of the low-permeability winter cover layer and caused seepage from the disposal cell sideslope. The layer was graded so that the seepage drained at a consistent elevation across the east sideslope of the cell. It was only after review of construction records, exploratory drilling and trenching, and extensive computer modeling that sideslope seepage was linked to the winter cover layer.

Additional design changes made in response to the proposed standards minimized infiltration through the disposal cell covers. In 1988, the bedding material specification was changed to provide a more free-draining material between the riprap on the cover surface and the radon/infiltration barrier. In addition to protecting the radon/infiltration barrier from riprap and water erosion damage, the bedding material provides lateral drainage at the surface of the radon/infiltration barrier before water significantly soaks into the barrier layer. Prior to 1988 , the bedding material specifications followed those used for dams or open channels. The flatter slopes and lower velocities of the disposal cell slopes allowed the use of a coarser gradation in the bedding material, promoting more rapid drainage of precipitation out of the cell. Radon barriers of the earlier designs became radon/infiltration barriers after 1987, with more attention paid to minimizing hydraulic conductivity. Vegetated topslopes were introduced as an alternative to rock covers to promote evapotranspiration, thereby reducing infiltration. 
HELP models were performed routinely to evaluate the cover system infiltration resistance. In 1989, a second revision of the UMTRA Project TAD was released that incorporated the latest design rationale [36].

The increased interest in minimizing infiltration through UMTRA covers coincided with the need to change the design of the Durango cover. Using the new TAD to provide design rationale, the radon/infiltration barrier at Durango was reinforced in its performance by placing a geosynthetic clay liner on the topslope and amending the sideslope radon/infiltration barrier material with bentonite clay.

The new emphasis on protecting ground water that resulted from the 1987 proposed standards also resulted in an increased effort to comprehend and explain the effects of transient drainage on the ground water under the cells. This information was needed to develop the ground water protection strategies required by the new regulations. Methods to determine mounding potential of contaminated water on the ground water table were examined, as well as ways of quantifying the amount and length of time of transient drainage.

In early 1988 the UMTRA Project obtained the UNSAT2 model for performing coupled analysis of saturated and unsaturated flow. This model was developed for the NRC in December 1983. Its application to the Green River disposal cell in April 1988 led to severely limiting construction water at that site.

Transient drainage was considered at all of the disposal sites that were completed after 1987, with respect to its effect on the ground water protection strategy. In many cases, particularly where supplemental standards were used as a protection strategy, analytically estimated transient drainage quantities were determined not to be a factor due to similar levels of ambient contamination in the ground water. Numerical modeling was used to analyze transient drainage where the potential for contamination was a concern, where transient drainage quantities might affect the disposal cell settlement and stability, and where transient drainage quantities and contamination might be measured beyond the edge of the disposal cell. This information is specifically addressed for each site in Section 4.0.

Because of these possible effects or because of problems with transient drainage that became evident after construction, a total of nine UMTRA Project disposal sites have been modeled. Some of the modeling results explain observed ground water profiles (e.g., the mounding of process water at Maybell). The modeling also resulted in design modifications such as those at the Rifle and Slick Rock disposal sites, where standpipes were installed in the cell to allow transient drainage water to be pumped out during construction.

Other modeling was performed to predict the movement of transient drainage water through wells located adjacent to the disposal site. This information is being included in site-specific long-term surveillance plans (LTSP) to identify the pulse of contaminated transient drainage water so that performance monitoring does not falsely indicate cell failure. The results of transient drainage analysis are used both as confirmation of existing conditions and prediction of future conditions. Predictive analysis uses existing data as benchmarks to obtain greater accuracy. It should be understood that while transient drainage can be calculated or predicted by analytical or numerical methods, it can be confirmed only by direct and/or indirect field measurements. 
The UMTRA Project has monitored transient drainage at some sites. Direct monitoring included monitoring water levels in standpipes at the Rifle disposal cell; monitoring the Green River cell for moisture changes; using borings at Salt Lake City to profile moisture distribution in the disposal cell; and recording water levels in the Durango disposal cell as part of the study of transient drainage-induced seepage. Indirect monitoring occurred at Grand Junction by monitoring water levels in the paleochannel wells and by observing consolidation using settlement monuments at most sites.

The need for additional analyses of transient drainage is not expected as part of surface remediation. The final ground water standards promulgated in 1995 did not differ significantly from the proposed standards used in design and did not affect UMTRA Project efforts to mitigate or evaluate transient drainage. The promulgation of 40 CFR $\$ 192.20(\mathrm{a})(2)$ [46] also has not affected the UMTRA Project designs at Maybell, Slick Rock, and Naturita. These three sites had not been completed before the regulation became effective. This regulation requires that new depository sites for tailings containing water at or greater than the level of "specific retention" have a liner or its equivalent. The three UMTRA sites that would be covered by this regulation are Slick Rock, Maybell, and Naturita. The tailings at Slick Rock have less water than their specific retention so no liner is required. The Maybell disposal cell is a SIP site so a liner cannot be placed without removing the existing tailings. The material at Naturita does not contain tailings, and consists of demolition debris and subpile soils that are predominately sands and gravels. Moreover, these materials will be drier than the specific retention, and no liner will be required. 


\subsection{DISPOSAL CELL INFORMATION}

This section provides information about each UMTRA Project site and cross sections of each UMTRA Project disposal cell (Figures 4.1 through 4.19). The cross sections depict the geology beneath the disposal cell to the top of the ground water. Other information pertinent to each disposal cell is provided in bullet form, including the type of cell: SIP, SOS, or relocated. Notes indicate the surface remediation ground water protection strategy applied to each site.

As discussed previously, the most common ground water protection strategy used for the disposal cells is supplemental standards. At sites with no significant tailings contamination, MCLs and/or background levels will not be exceeded and ground water protection is achieved based on this. Canonsburg, Burrell, Salt Lake City, and Shiprock disposal cells essentially were complete prior to the 1987 proposed standards and have been "grandfathered." Grandfathering allows these sites to be left as designed and constructed, without proving compliance with the 1987 standard and obtaining new NRC concurrence. Grandfathering does not preclude additional action, should future contamination from a disposal cell threaten ground water.

Modeling and other analyses are noted also. In some cases qualitative arguments have ruled out the effects of transient drainage on ground water quality or quantity.

Quantitative information concerning the amount of tailings, both in place and relocated, is useful in assessing the impact of consolidation on transient drainage as in-place tailings are loaded by relocated tailings. The average yearly rainfall at the site (given in inches) can be compared to the infiltration of the cover (given in inches per year) to assess the cover infiltration performance.

It should be noted that the current preliminary ground water remediation strategies are based on planning documents. They are subject to change after completion of the final programmatic environmental impact statement or environmental assessment and the site-specific National Environmental Policy Act documents. 
AMBROSIA LAKE, NEW MEXICO

- Cell type

- Cell area

- Amount of tailings in cell

In place

Relocated

- Ground water protection strategy

- Proposed ground water remediation program

- Yearly precipitation

- Cover infiltration
Stabilized in place/stabilized on site

82 acres

2,421,933 cubic yards

$2,741,471$ cubic yards

Supplemental standards

No further action

8.83 inches

1.24 inches per year

Notes: 1. Supplemental standards compliance is based on insufficient yield of the alluvium/weathered rock that is the uppermost aquifer at the site. Additionally, water in the aquifer cannot be used and has not been used in the past for drinking or other beneficial purposes including livestock watering or irrigation, because of poor quality conditions that existed prior to processing activities.

2. Transient drainage was not modeled at this site because the additional contamination from transient drainage will not affect compliance with the ground water standards.

\section{References:}

3. DOE (U.S. Department of Energy), 1995. Long-Term Surveillance Plan for the Ambrosia Lake, New Mexico, Disposal Site, DOE/AL/62350-211, Rev. 0, November 1995, prepared for the U.S. Department of Energy, UMTRA Project Team, Albuquerque Operations Office, Albuquerque, New Mexico.

7. DOE (U.S. Department of Energy), 1995. Site Observational Work Plan for the UMTRA Project Site at Ambrosia Lake, New Mexico, Rev. 0, UMTRA-DOE/AL-62350-159, prepared for the U.S. Department of Energy, UMTRA Project Office, Albuquerque Operations Office, Albuquerque, New Mexico.

29. DOE (U.S. Department of Energy), 1991. Remedial Action Plan and Site Design for Stabilization of the Inactive Uranium Mill Tailings at Ambrosia Lake, New Mexico, final, UMTRA-DOE/AL-050516.0000, DOE UMTRA Project Office, Albuquerque Operations Office, Albuquerque, New Mexico, February 1991. 


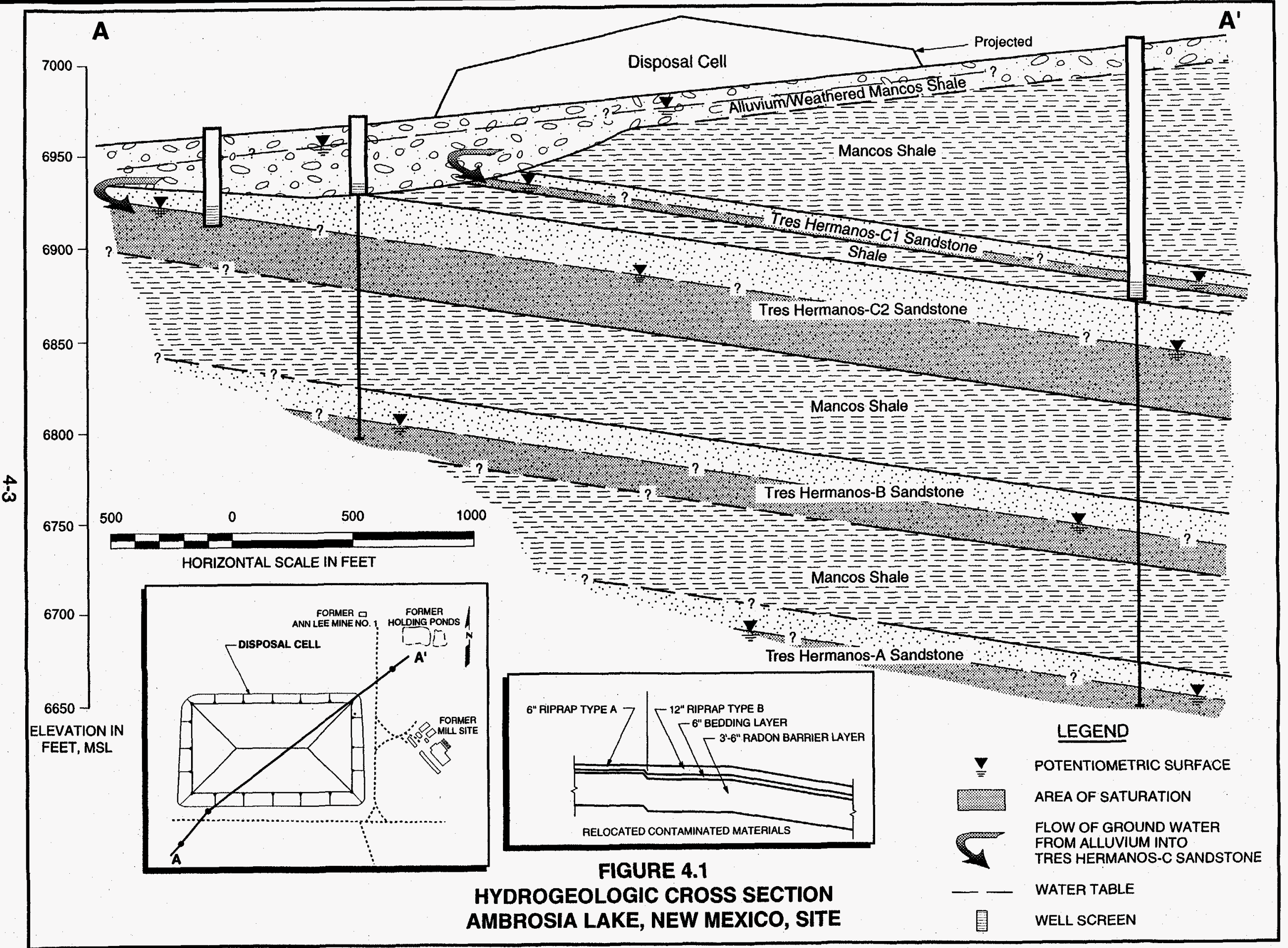




\section{BURRELL SITE, CANONSBURG, PENNSYLVANIA}

- Cell type

- Cell area

- Amount of tailings in cell

- Ground water protection strategy

- Ground water remediation program

- Yearly precipitation

- Cover infiltration
Stabilized in place

72 acres

53,000 cubic yards

Grandfathered

Not applicable

44 inches

1.24 inches per year

Note: Remedial action at this site was completed prior to the introduction of the 1987 proposed ground water standards. The NRC did not require proof of compliance with the standards. Should contamination of the ground water become an issue in the future, the design and construction will be reviewed for corrective action.

\section{Reference:}

17. DOE (U.S. Department of Energy), 1993. Burrell, Pennsylvania, Vicinity Property LongTerm Surveillance Plan, final, DOE/AL-62350-3F, prepared by the U.S. Department of Energy, UMTRA Project Office, Albuquerque Operations Office, Albuquerque, New Mexico, September 1993. 


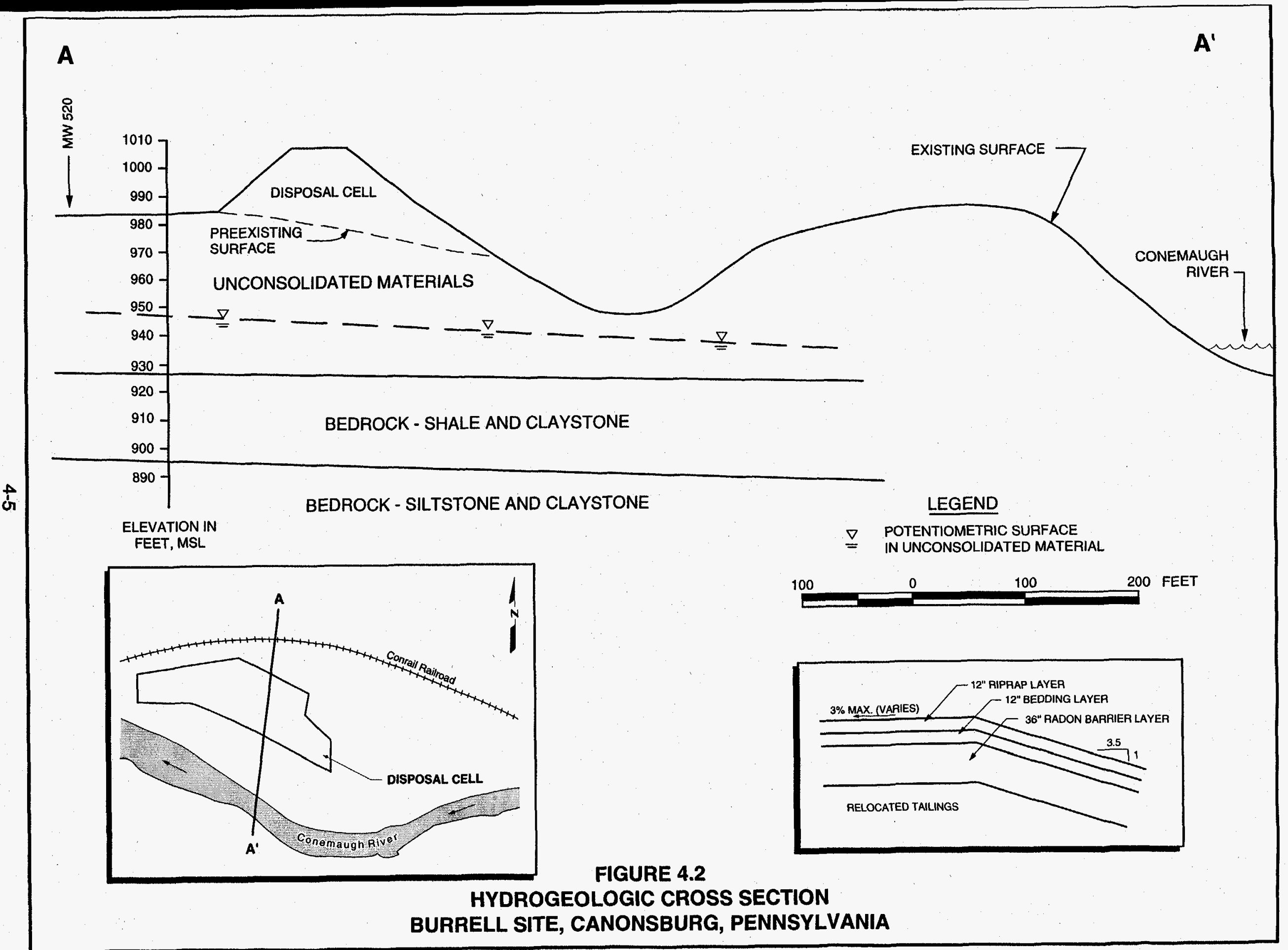


CANONSBURG, PENNSYLVANIA

- Cell type

- Cell area

- Amount of tailings in cell

- Ground water protection strategy

- Proposed ground water remediation program

- Yearly precipitation

- Cover infiltration
Stabilized in place

30 acres

172,000 cubic yards

Grandfathered

Alternate concentration limits, no further action

37 inches

1.24 inches per year

Note: Remedial action at this site was completed prior to the introduction of the 1987 proposed ground water standards. The NRC did not require proof of compliance with the standards. Should contamination of the ground water become an issue in the future, the design and construction will be reviewed for corrective action.

\section{References:}

4. DOE (U.S. Department of Energy), 1995. Long-Term Surveillance Plan for the Canonsburg, Pennsy/vania, Disposal Site, DOE/AL/62350-203, Rev. 0, October 1995, prepared for the U.S. Department of Energy, UMTRA Project Team, Albuquerque Operations Office, Albuquerque, New Mexico.

42. DOE (U.S. Department of Energy), 1983. Remedial Action Plan for Stabilization of the Inactive Uranium Mill Tailings Site at Canonsburg, Pennsylvania, UMTRA-DOE/AL140, prepared for the U.S. Department of Energy, UMTRA Project Office, Albuquerque Operations Office, Albuquerque, New Mexico. 
A
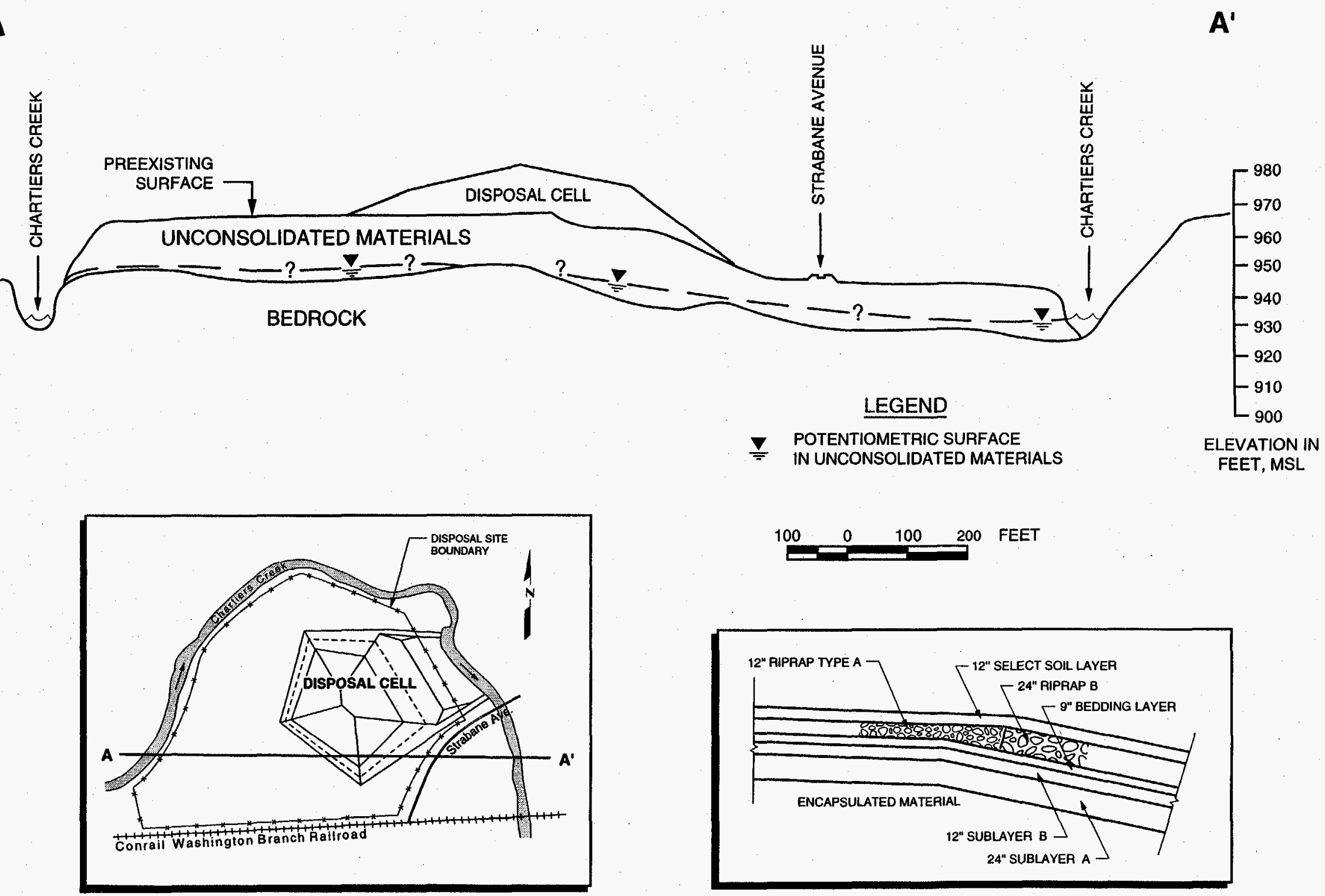

FIGURE 4.3

HYDROGEOLOGIC CROSS SECTION

CANONSBURG, PENNSYLVANIA, SITE 


\section{DURANGO (Bodo Canyon), COLORADO}

- Cell type

- Cell area

- Amount of tailings in cell

- Ground water protection strategy

- Ground water remediation program

- Yearly precipitation

- Cover infiltration
Relocated

60 acres

2,533,000 cubic yards

Proposed concentration limits

Not applicable

18.69 inches

0.06 inches per year

Notes: 1. The disposal cell covers 85 percent of the Bodo Canyon drainage divide area. The low-permeability cover has reduced recharge in the alluvium below the cell and the rate of transient drainage into the alluvium is less than the pre-disposal cell recharge, resulting in desaturation of the alluvium. Transient drainage will reach the uppermost aquifer, located in the shallowest bedrock unit, as unsaturated flow through the alluvium. The rate of ground water flow in the uppermost aquifer is sufficient to dilute the transient drainage contamination to below the proposed concentration limits.

2. The desaturation of the alluvium was predicted by the transient drainage modeling [47] and was verified by field measurements. The transient drainage modeling was used to model flow out of a toe drain constructed during remedial action. The toe drain was installed to intercept transient drainage flow as it collects at the toe a low-permeability interim cover placed during a winter shutdown during cell construction.

\section{References:}

5. DOE (U.S. Department of Energy), 1995. Long-Term Surveillance Plan for the Bodo Canyon Disposal Site, Durango, Colorado, DOE/AL/62350-77, Rev. 1, Ver. 4, November 1995, prepared for the U.S. Department of Energy, UMTRA Project Team, Albuquerque Operations Office, Albuquerque, New Mexico.

30. DOE (U.S. Department of Energy), 1991. Remedial Action Plan and Site Design for Stabilization of the Inactive Uranium Mill Tailings at Durango, Colorado, revised final, UMTRA-DOE/AL-050503.0000, DOE UMTRA Project Office, Albuquerque Operations Office, Albuquerque, New Mexico, December 1991.

47. Durango-Bodo Canyon Toe Drain Study Report (Draft) and Supporting Documentation, UPDCC Remote Box No. 978, Albuquerque, New Mexico. 


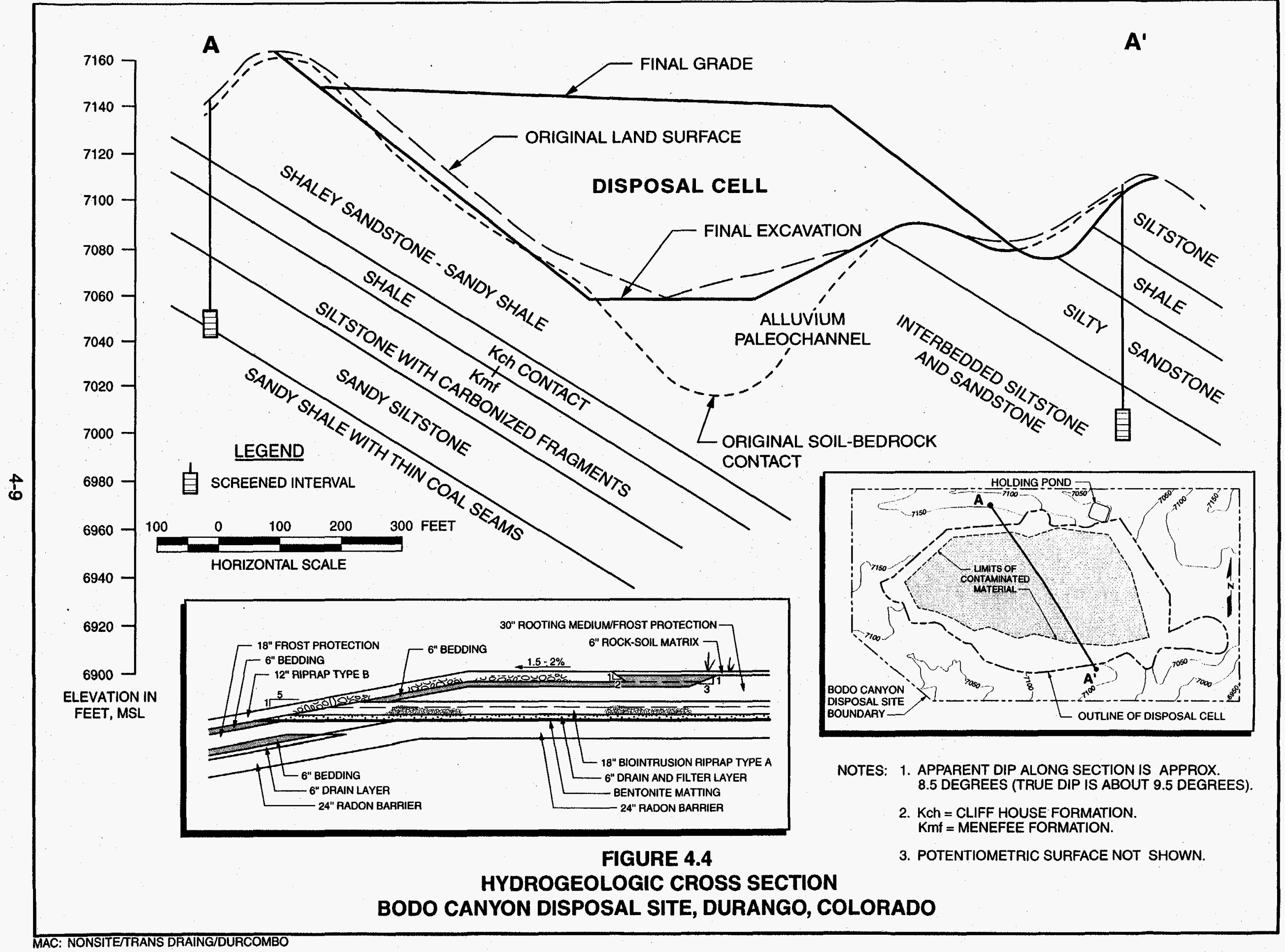




\section{FALLS CITY, TEXAS}

- Cell type

- Cell area

- Amount of tailings in cell In place Relocated

- Ground water protection strategy

- Proposed ground water remediation program

- Yearly precipitation

- Cover infiltration
Stabilized in place/stabilized on site

125 acres

$3,521,000$ cubic yards

$3,996,000$ cubic yards

Supplemental standards

No further action

30.3 inches

0.05 inches per year

Notes: 1. The supplemental standards ground water protection strategy is based on widespread ambient contamination that is due to a naturally occurring mineralized zone in the area. This condition existed prior to processing and disposal.

2. Transient drainage was modeled for the Falls City cell to demonstrate that the vegetative cover would help reduce cover infiltration and water flow through the cell (Calc. No. FCT-12-89-02-09-01). Modeling was not required to support the ground water protection strategy.

\section{References:}

6. DOE (U.S. Department of Energy), 1995. Long-Term Surveillance Plan for the Falls City Disposal Site, Falls City, Texas, DOE/AL/62350-187, Rev. 1, June 1995, prepared for the U.S. Department of Energy, UMTRA Project Office, Albuquerque Operations Office, Albuquerque, New Mexico.

8. DOE (U.S. Department of Energy), 1995. Site Observational Work Plan for the UMTRA Project Site at Falls City, Texas, DOE/AL/62350-157, Rev. 0, June 1995, prepared for the U.S. Department of Energy, UMTRA Project Office, Albuquerque Operations Office, Albuquerque, New Mexico.

25. DOE (U.S. Department of Energy), 1992. Remedial Action Plan and Site Design for Stabilization of the Inactive Uranium Mill Tailings Site at Falls City, Texas, final, DOE/AL-050520.0000, DOE UMTRA Project Office, Albuquerque Operations Office, Albuquerque, New Mexico, September 1992. 


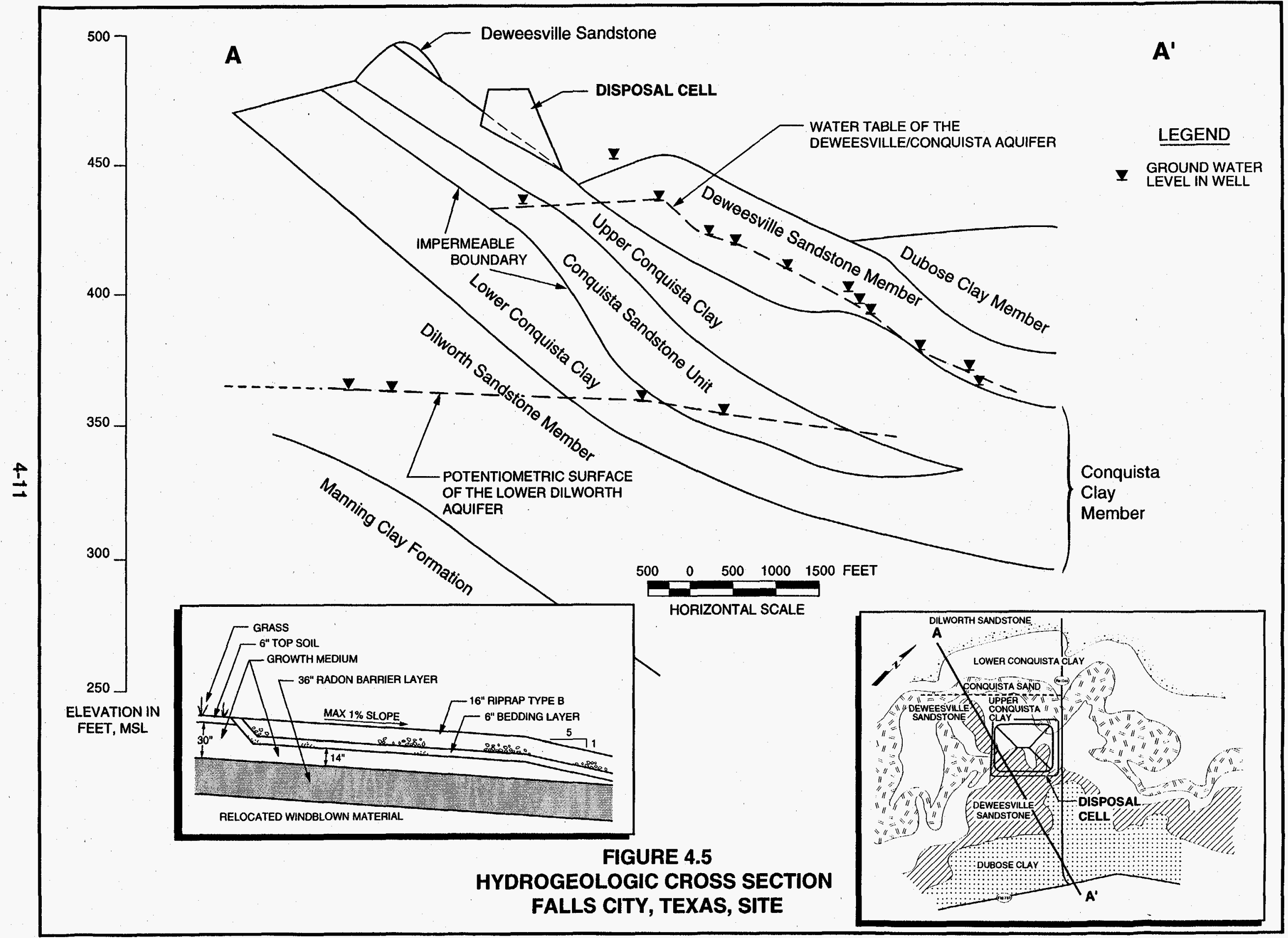




\section{GRAND JUNCTION (Cheney Reservoir), COLORADO}

- Cell type

- Cell area

- Amount of tailings in cell

- Ground water protection strategy

- Ground water remediation program

- Yearly precipitation

- Cover infiltration
Relocated

60 acres

$5,260,300$ cubic yards

Supplemental standards

Not applicable

9 inches

1.24 inches per year

Notes: 1. Supplemental standards compliance was based on limited use water in the uppermost aquifer due to total dissolved solids levels greater than $10,000 \mathrm{mg} / \mathrm{L}$ prior to disposal. Also there is hydrologic isolation of the uppermost Dakota Sandstone aquifer from the disposal cell.

2. Transient drainage was modeled for this site to determine if water would "bathtub" on top of the underlying, low-permeability rock or would be able to drain out of the bottom at the same rate it drained from the tailings (Calc. No. GRJ-05-91-12-05$00)$. The results showed the transient drainage will collect at the bottom of the disposal cell, but the water level will be below that of the paleochannels at the site.

\section{References:}

2. DOE (U.S. Department of Energy), 1996. Site Observational Work Plan for the UMTRA Project Site at Grand Junction, Colorado, DOE/AL/62350-215, Rev. 0, January 1996, prepared for the U.S. Department of Energy, Grand Junction Projects Office, Grand Junction, Colorado.

31. DOE (U.S. Department of Energy), 1991. Remedial Action Plan and Final Design for Stabilization of the Inactive Uranium Mill Tailings at Grand Junction, Colorado, final, UMTRA-DOE/AL-050505.0000, DOE UMTRA Project Office, Albuquerque Operations Office, Albuquerque, New Mexico, September 1991. 


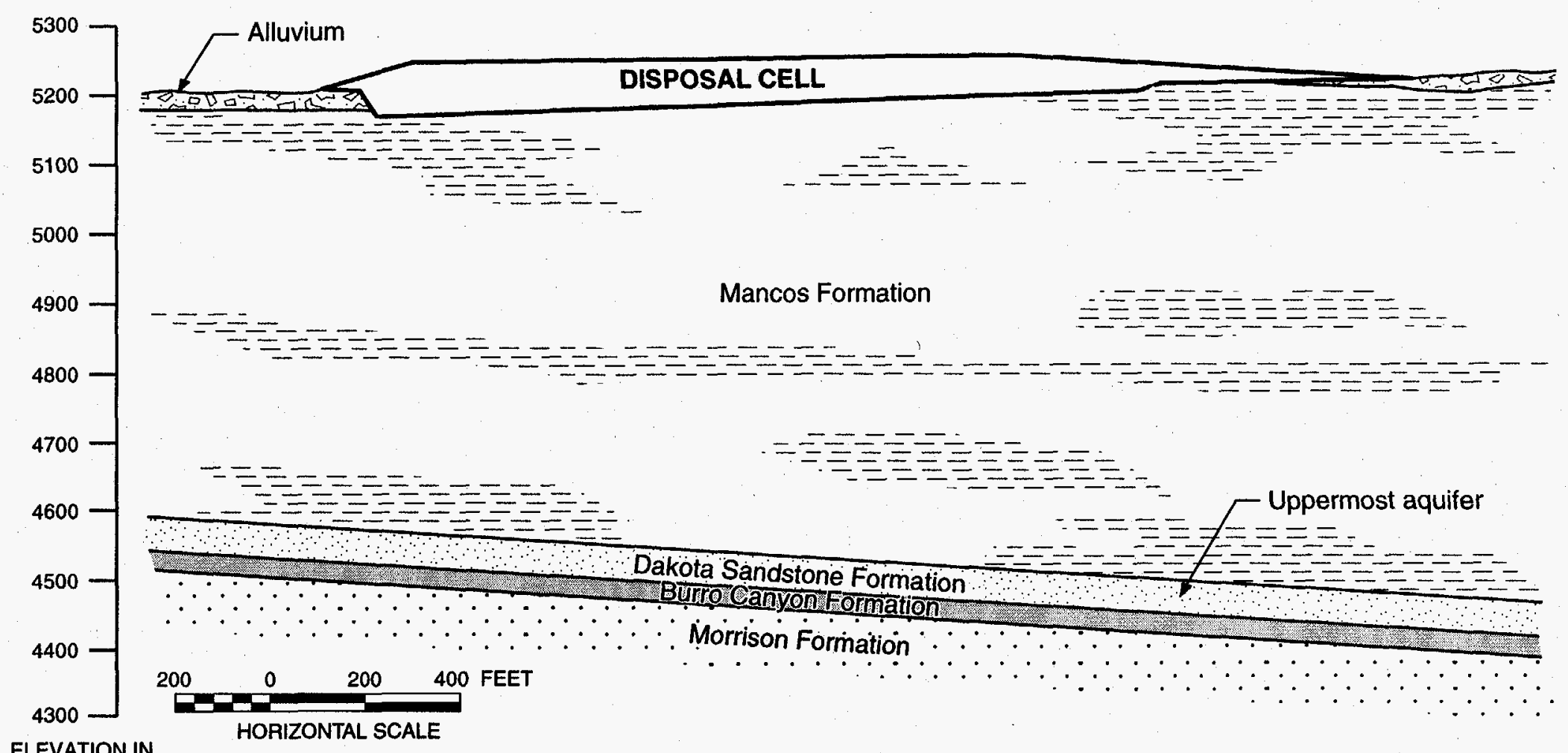

ELEVATION IN

FEET, MSL
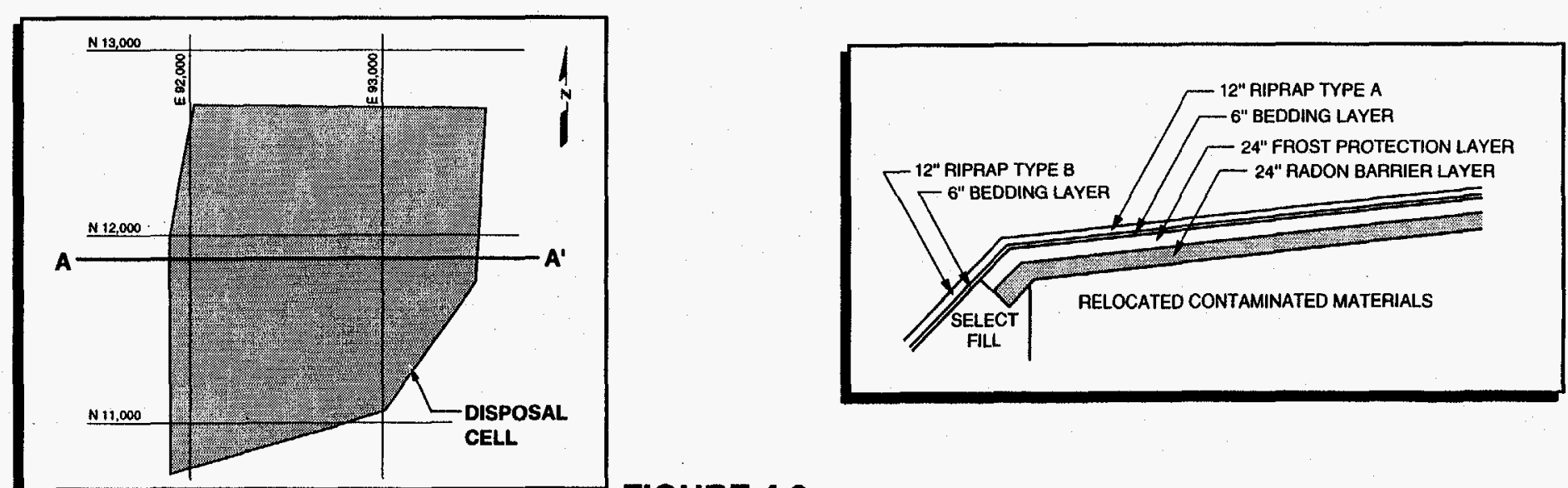

FIGURE 4.6

HYDROGEOLOGIC CROSS SECTION, CHENEY DISPOSAL CELL GRAND JUNCTION, COLORADO, SITE 


\section{GREEN RIVER, UTAH}

- Cell type Stabilized on site

- Cell area

6 acres

- Amount of tailings in cell

In place

Relocated

- Ground water protection strategy

204,249 cubic yards

177,512 cubic yards

- Proposed ground water remediation

Supplemental standards program

- Yearly precipitation

No further action

- Cover infiltration

6.2 inches

0.25 inches per year

Notes: 1. The supplemental standards protection strategy is based on limited use of the uppermost aquifer due to widespread, naturally occurring, ambient contamination. The slimes at Green River were taken to Rifle for reprocessing, leaving only sands that drained rapidly and had low (15 to 25 percent) saturation during placement, thus limiting transient drainage amount and duration time. A buffer layer was placed at the base of the cell to protect against rapid fingering and preferential flow paths of transient drainage through the unsaturated zone.

2. Transient drainage was modeled for this site and showed the potential for the resulting contamination to affect the ground water if severe construction water limitations were not imposed. As a result, the design was changed to improve the control of infiltration through the cover and extreme measures were taken to limit added water during construction.

\section{References:}

13. DOE (U.S. Department of Energy), 1994. Long-Term Surveillance Plan for the Green River, Utah, Disposal Site, DOE/AL/62350-89F, Rev. 1, August 1994, prepared for the U.S. Department of Energy, UMTRA Project Office, Albuquerque Operations Office, Albuquerque Operations Office, Albuquerque, New Mexico.

32. DOE (U.S. Department of Energy), 1991. Remedial Action Plan and Final Design for Stabilization of the Inactive Uranium Mill Tailings at Green River, Utah, final, UMTRA-DOE/AL-050510.GRNO, DOE UMTRA Project Office, Albuquerque Operations Office, Albuquerque, New Mexico, March 1991. 


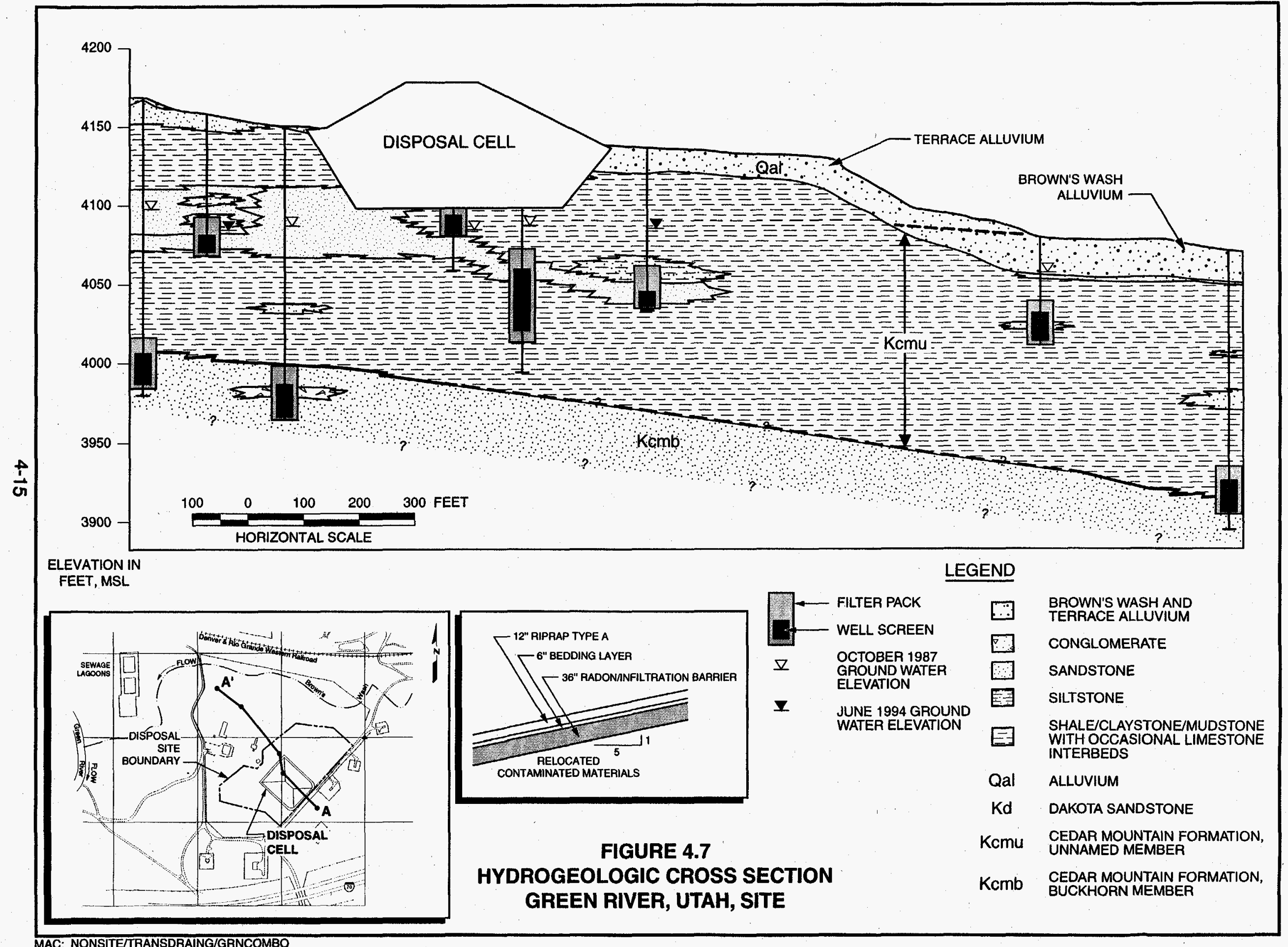




\section{GUNNISON, COLORADO}

- Cell type Relocated

- Cell area

29 acres

- Amount of tailings in cell

798,000 cubic yards

- Ground water protection strategy

Maximum concentration limits

- Ground water remediation program

Not applicable

- Yearly precipitation

11 inches

- Cover infiltration

1.24 inches per year

Note: Transient drainage and contaminant transport were modeled to support the $\mathrm{MCL}$ ground water protection strategy (Calc. No. GUN-03-91-02-04-01). Modeling indicates drainage from the cell would not cause constituent concentrations in the ground water to exceed EPA MCLs.

\section{Reference:}

26. DOE (U.S. Department of Energy), 1992. Remedial Action Plan and Site Design for Stabilization of the Inactive Uranium Mill Tailings Site at Gunnison, Colorado, final, DOE/AL-050508.0000, DOE UMTRA Project Office, Albuquerque Operations Office, Albuquerque, New Mexico, October 1992. 


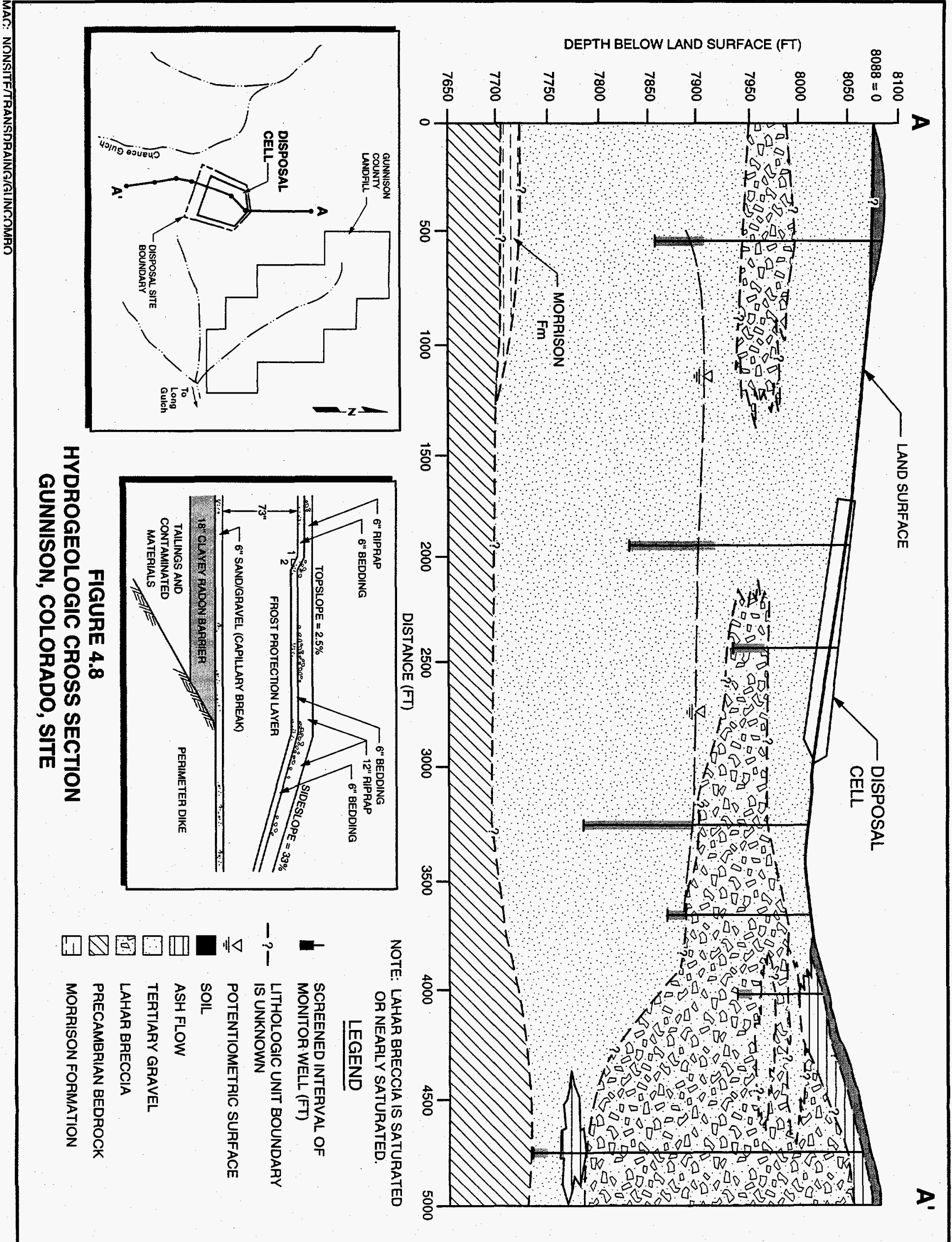




\section{LAKEVIEW (Collins Ranch), OREGON}

- Cell type

- Cell area

- Amount of tailings in cell

- Ground water protection strategy

- Ground water remediation program

- Yearly precipitation

- Cover infiltration
Relocated

30 acres

944,000 cubic yards

Maximum concentration limits

Not applicable

16 inches

1.24 inches per year

Note: Design of the Lakeview cell was completed well before the 1987 EPA proposed ground water standards were adopted. Therefore, no transient drainage modeling was performed. A geochemical barrier was designed and installed in the bottom of the cell to provide additional assurance that ground water would not be adversely impacted.

\section{References:}

23. DOE (U.S. Department of Energy), 1992. Long-Term Surveillance and Maintenance Plan for the Lakeview, Oregon, Disposal Site, final, UMTRA-DOE/AL-350213.0000, DOE UMTRA Project Office, Albuquerque Operations Office, Albuquerque, New Mexico, September 1992.

27. DOE (U.S. Department of Energy), 1992. Remedial Action Plan and Site Design for Stabilization of the Inactive Uranium Mill Tailings Site at Lakeview, Oregon, final, DOE/AL-050510.0000, Rev. 1, DOE UMTRA Project Office, Albuquerque Operations Office, Albuquerque, New Mexico, July 1992. 


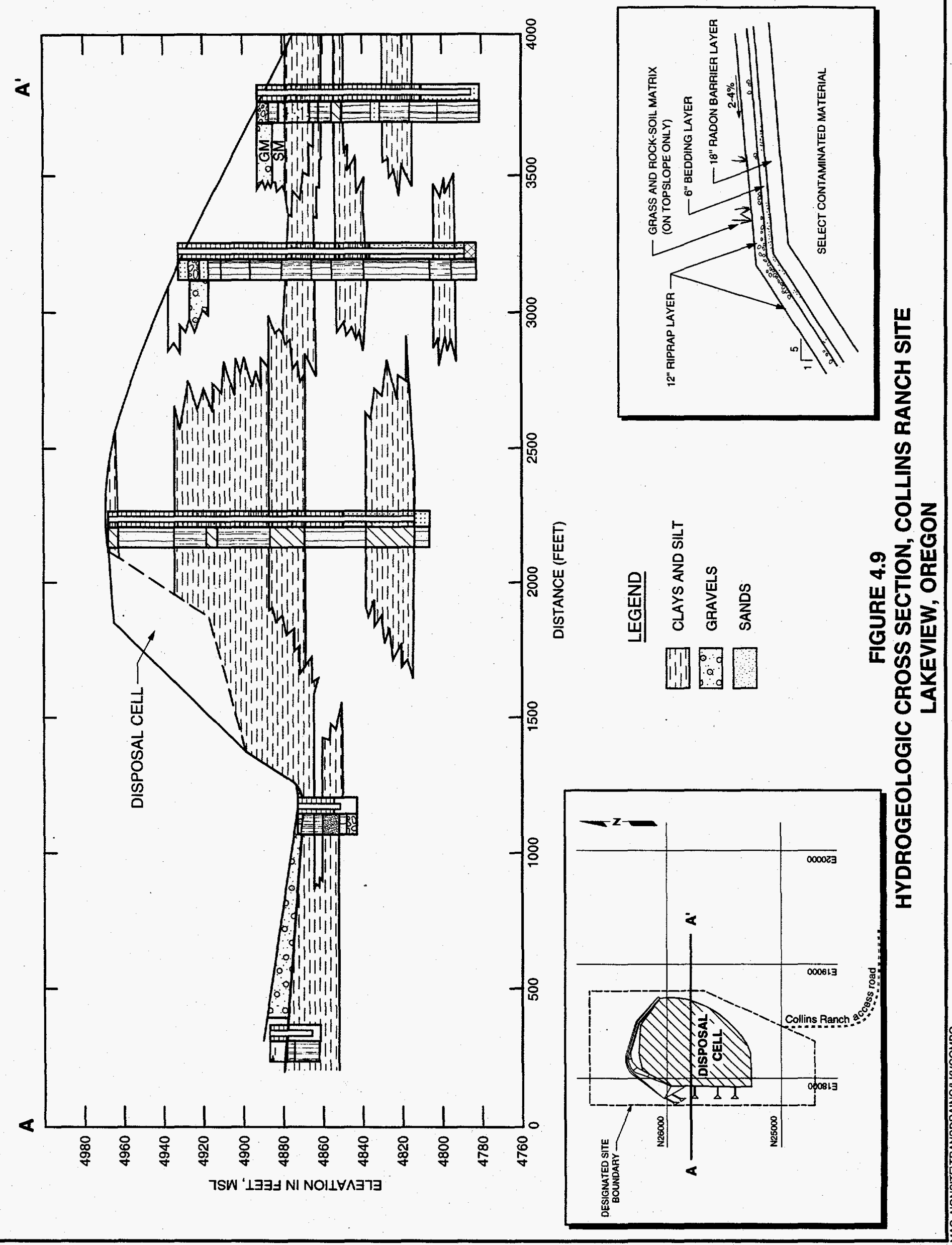




\section{LOWMAN, IDAHO}

- Cell type

- Cell area

- Amount of tailings in cell

- Ground water protection strategy

- Ground water remediation program

- Yearly precipitation

- Cover infiltration
Stabilized in place

9 acres

129,400 cubic yards

MCLs and background

Not applicable

24 inches

24 inches per year

Note: The tailings at Lowman have little contamination. Consequently, transient drainage from the disposal cell, when mixed with the ground water, will not exceed the MCLs. No transient drainage modeling was needed to make this determination.

\section{References:}

18. DOE (U.S. Department of Energy), 1993. Long-Term Surveillance Plan for the Lowman, Idaho, Disposal Site, preliminary final, DOE/AL/62350-36PF, U.S. Department of Energy, UMTRA Project Office, Albuquerque Operations Office, Albuquerque, New Mexico, September 1993.

33. DOE (U.S. Department of Energy), 1991. Remedial Action Plan and Site Design for Stabilization of the Inactive Uranium Mill Tailings at the Lowman Site, Lowman, Idaho, UMTRA-DOE/AL-050512.0000, September 1991, prepared by the U.S. Department of Energy, UMTRA Project Office, Albuquerque Operations Office, Albuquerque, New Mexico. 


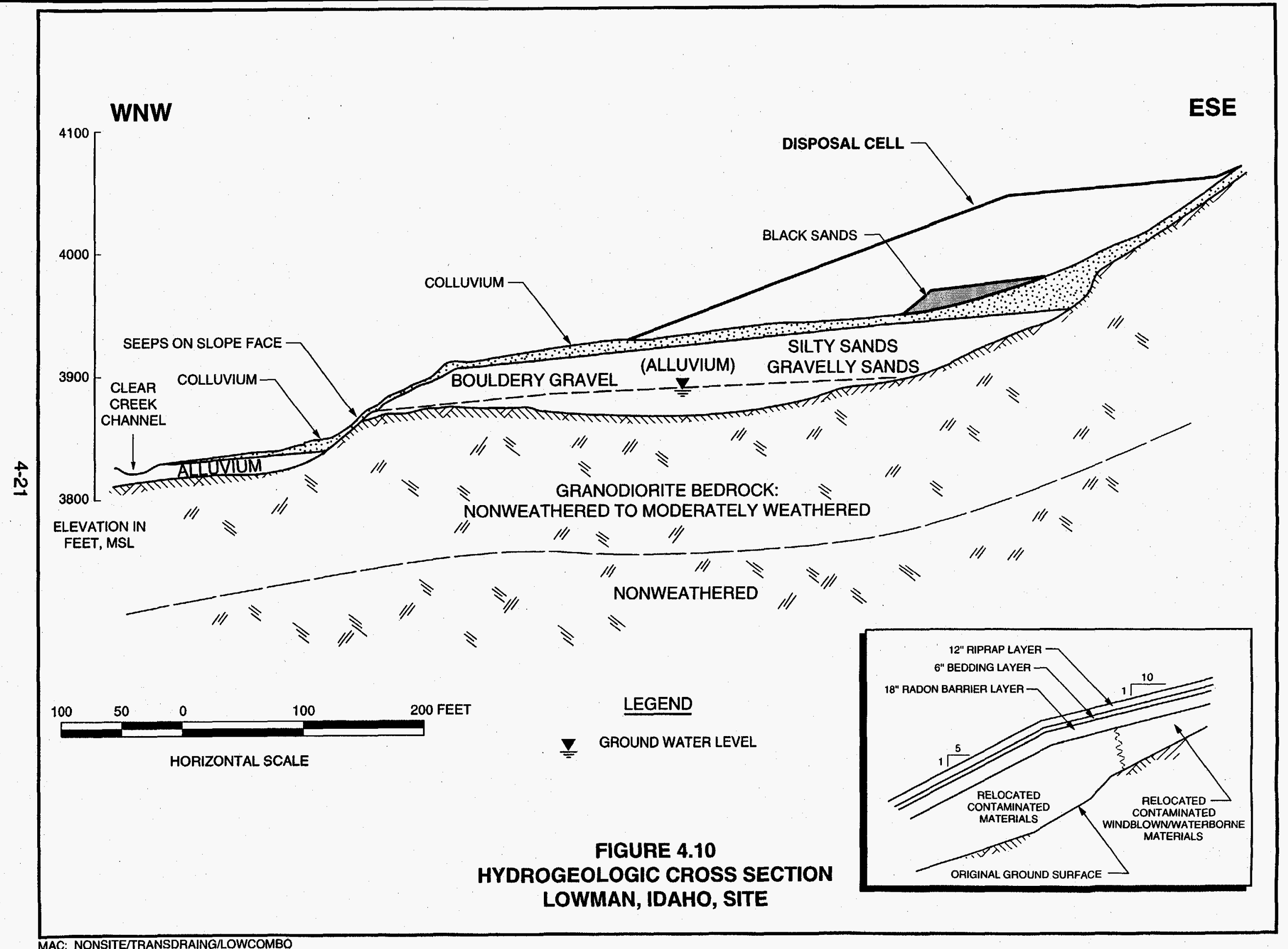




\section{MAYBELL, COLORADO}

- Cell type

- Cell area

- Amount of tailings in cell In place Relocated

- Ground water protection strategy

- Proposed ground water remediation program

- Yearly precipitation

- Cover infiltration
Stabilized in place

66 acres

$2,800,000$ cubic yards 700,000 cubic yards

Supplemental standards

No further action

13.29 inches

1.24 inches per year

Notes: 1. Supplemental standards protection was based on limited use water in the uppermost aquifer due to widespread, ambient contamination from natural sources. This contamination was present prior to processing at this site.

2. Initial modeling at this site was performed to determine the quantity of transient drainage due to consolidation. The potential for mounding of the consolidation water led to modeling using the SEEP/W code (Calc. No. MAY-03-96-12-95-00). Modeling shows a large mound of contaminated water resulting from processing, which was verified through field measurements. The model was used to predict the mounding of the transient drainage from remedial action to avoid incorrectly assuming cell failure. Results of this modeling are included in the LTSP.

\section{Reference:}

16. DOE (U.S. Department of Energy), 1994. Remedial Action Plan and Site Design for Stabilization of the Inactive Mill Tailings Site, Maybell, Colorado, DOE/AL-6235024F, June 1994, prepared for the U.S. Department of Energy, UMTRA Project Office, Albuquerque Operations Office, Albuquerque, New Mexico. 

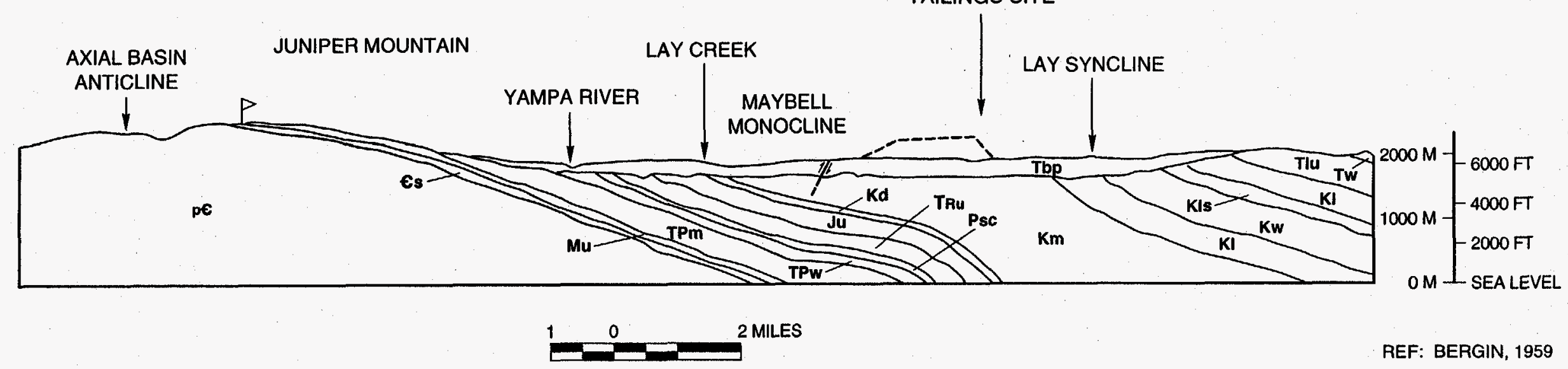

REF: BERGIN, 1959

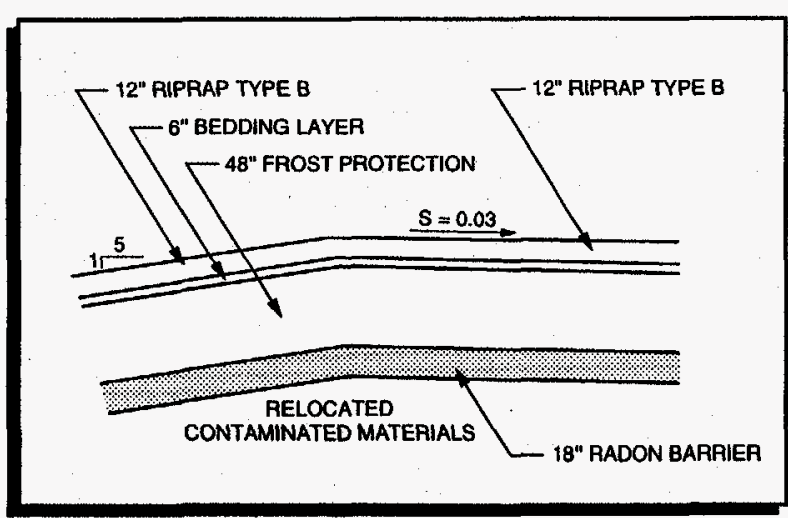

\begin{tabular}{|c|c|c|}
\hline \multicolumn{3}{|c|}{ EXPLANATION } \\
\hline PERIOD & & EORMATIONS \\
\hline TERTIARY & & $\begin{array}{l}\text { BROWNS PARK } \\
\text { WASATCH } \\
\text { FORT UNION }\end{array}$ \\
\hline CRETACEOUS & $\begin{array}{r}\mathbf{K I} \\
\mathbf{K l} \mathbf{s} \\
\mathbf{K W} \\
\mathbf{K} \mathbf{K} \\
\mathbf{K m} \\
\mathbf{K d}\end{array}$ & $\begin{array}{l}\text { LANCE } \\
\text { LEWIS SHALE } \\
\text { WLLLIAMS FORK } \\
\text { ILES } \\
\text { MANCOS SHALE } \\
\text { DATOTA }\end{array}$ \\
\hline JURASSIC & Ju & UNDIVIDED ROCKS \\
\hline TRIASSIC & Ru & UNDIVIDED ROCKS \\
\hline PERMIAN & Psc & $\begin{array}{l}\text { SOUTH CANYONI } \\
\text { MAROON FM. }\end{array}$ \\
\hline PENNSYLVANIAN & $\begin{array}{l}\text { TPW } \\
\text { TPm }\end{array}$ & $\begin{array}{l}\text { WEBER SANDSTONE } \\
\text { MORGAN }\end{array}$ \\
\hline MISSISSIPPIAN & Mu & UNDIVIDED ROCKS \\
\hline CAMBRIAN & $\epsilon_{8}$ & SAWATCH \\
\hline PRECAMBRIAN. & pe & UINTA MTN. GROUP \\
\hline
\end{tabular}

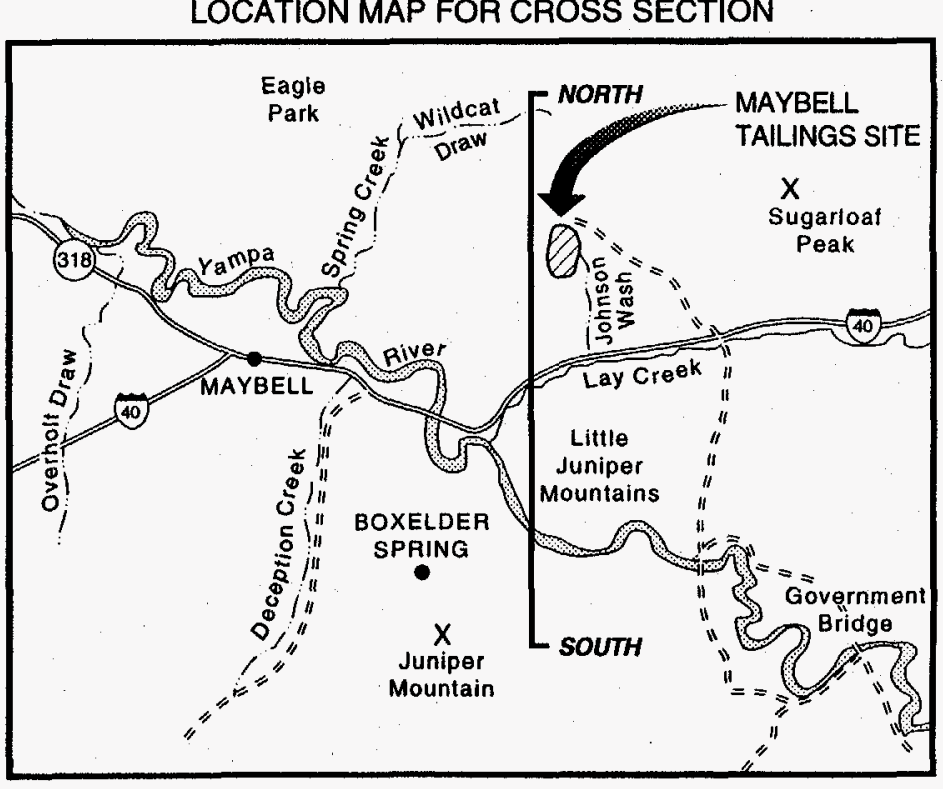

FIGURE 4.11

STRUCTURAL CROSS SECTION

MAYBELL, COLORADO, SITE 


\section{MEXICAN HAT, UTAH}

- Cell type

- Cell area

- Amount of tailings in cell In place Relocated Relocated (Monument Valley)

- Ground water protection strategy

- Proposed ground water remediation program

- Yearly precipitation

- Cover infiltration
Stabilized in place/relocated

60 acres

$1,600,000$ cubic yards

$1,210,000$ cubic yards

$1,100,000$ cubic yards

Background levels, maximum concentration limits

No further action

6.87 inches

0.06 inches per year

Note: A water balance calculation was performed (Calc. No. HAT-11-91-12-02). It indicated that ground water MCLs would not be exceeded. Transient drainage was not modeled.

\section{References:}

1. DOE (U.S. Department of Energy), 1996. Long-Term Surveillance Plan for the Mexican Hat Disposal Site, Mexican Hat, Utah, DOE/AL/62350-207, Rev. 1, February 1996, prepared for the U.S. Department of Energy, Environmental Restoration Division, UMTRA Project Team, Albuquerque, New Mexico.

12. DOE (U.S. Department of Energy), 1995. UMTRA Project Site Observational Work Plan, Mexican Hat, Utah, DOE/AL/62350-153, Rev. 0, September 1995, prepared for the U.S. Department of Energy, Environmental Restoration Division, UMTRA Project Team, Albuquerque, New Mexico.

22. DOE (U.S. Department of Energy), 1993. Remedial Action Plan for the Codisposal and Stabilization of the Monument Valley and Mexican Hat Uranium Mill Tailings at Mexican Hat, Utah, final, UMTRA-DOE/AL 050509.0000, prepared by the U.S. Department of Energy, UMTRA Project Office, Albuquerque Operations Office, Albuquerque, New Mexico, February 1993.

37. DOE (U.S. Department of Energy), 1988. Remedial Action Plan and Site Design for Stabilization of the Inactive Uranium Mill Tailings Site at Mexican Hat, Utah, UMTRA-DOE/AL-050509.0000, prepared by the U.S. Department of Energy, UMTRA Project Office, Albuquerque Operations Office, Albuquerque, New Mexico.

38. DOE (U.S. Department of Energy), 1986. Remedial Action Plan and Site Conceptual Design for Stabilization of the Inactive Uranium Mill Tailings Site at Monument Valley, Arizona, unpublished draft, prepared by the U.S. Department of Energy, UMTRA Project Office, Albuquerque Operations Office, Albuquerque, New Mexico. 


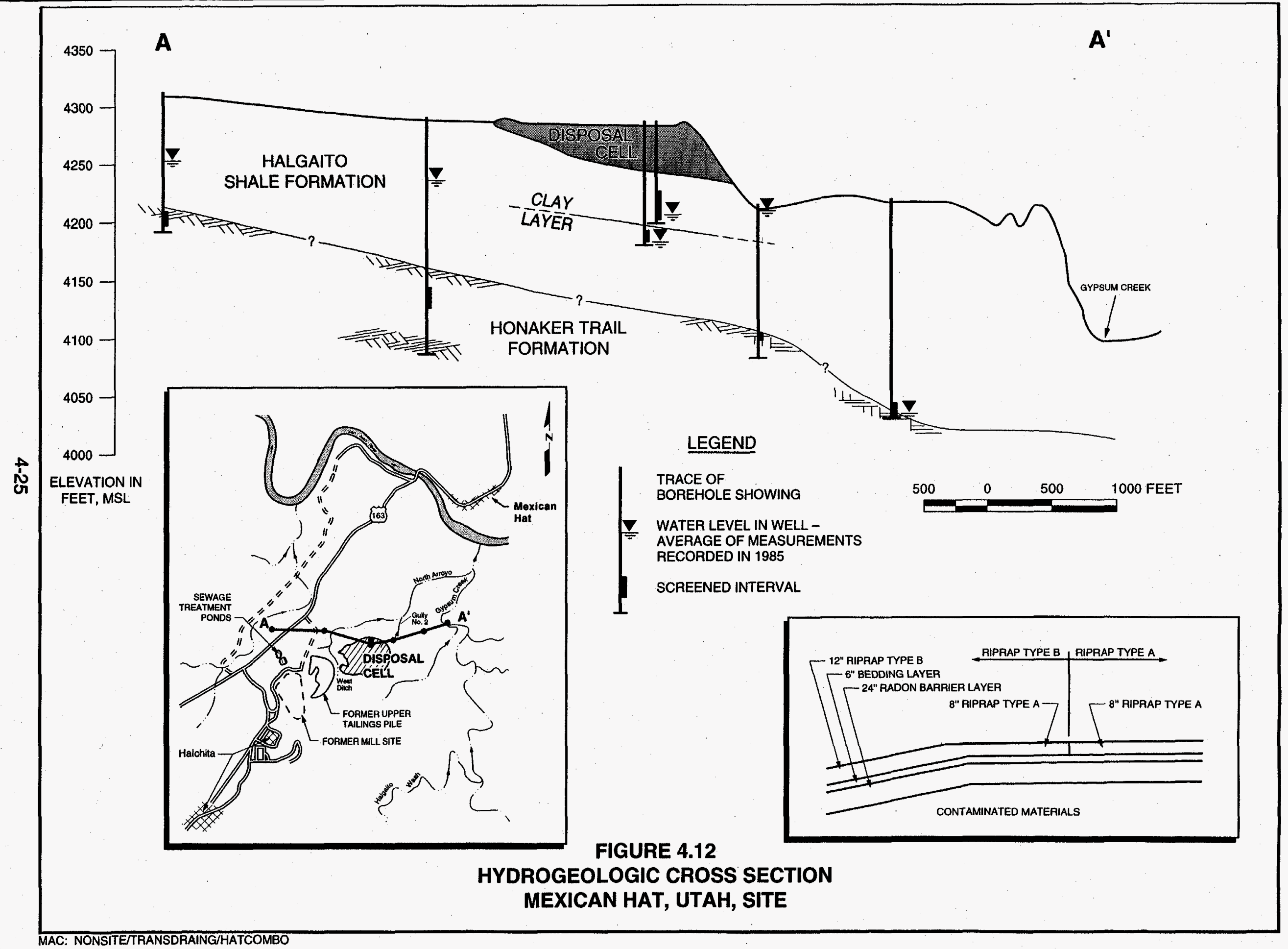




\section{NATURITA (Uravan), COLORADO}

- Cell type

- Cell area

- Amount of tailings in cell

- Ground water protection strategy

- Ground water remediation program

- Yearly precipitation

- Cover infiltration
Relocate

10 acres

401,000 cubic yards

Geologic isolation, maximum concentration limits

Not applicable

10.5 inches

1.24 inches per year

Notes: 1. The rate of transient drainage from the site is much less than that anticipated from infiltration through the cover, and therefore is not likely to impact the ground water.

2. The Naturita contaminated material consists primarily of sands and gravels from the subpile area. These materials are below their specific retention (dry). Additionally, water leaving the cell will exit as unsaturated flow and must travel through hundreds of feet of unsaturated strata and an aquitard layer before reaching the uppermost aquifer.

\section{Reference:}

14. DOE (U.S. Department of Energy), 1994. Remedial Action Plan for the Inactive Uranium Processing Site at Naturita Colorado, DOE/AL/62350-142, Rev. 0, prepared for the U.S. Department of Energy, UMTRA Project Office, Albuquerque Operations Office, Albuquerque, New Mexico. 


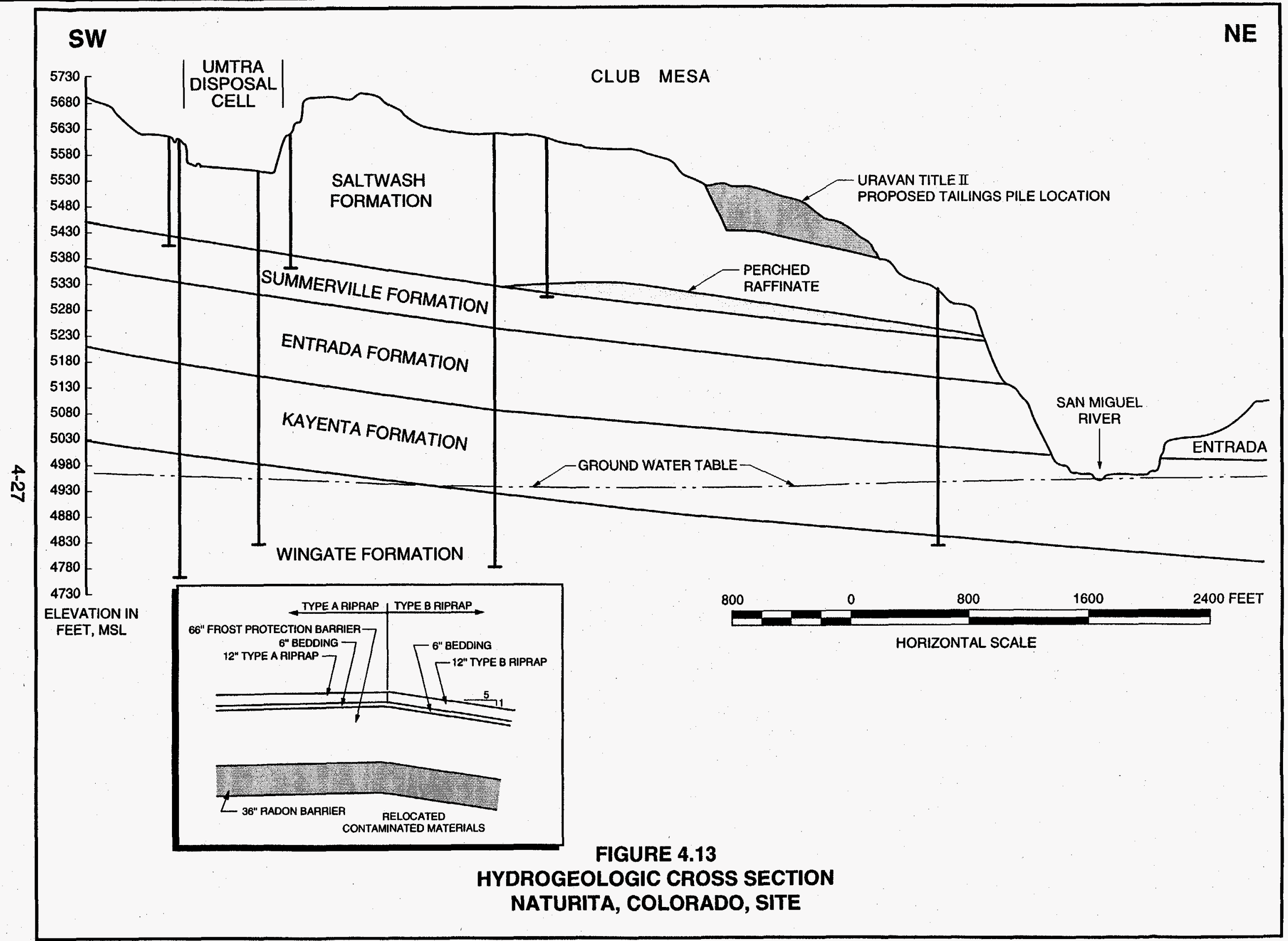




\section{RIFLE (Estes Gulch), COLORADO}

- Cell type

- Cell area

- Amount of tailings in cell

- Ground water protection strategy

- Ground water remediation program

- Yearly precipitation

- Cover infiltration
Relocated

71 acres

$2,756,000$ cubic yards

Supplemental standards

Not applicable

11.02 inches

1.24 inches per year

Notes: 1. Contamination of the ground water as a result of transient drainage will not occur due to geologic isolation of the uppermost aquifer.

2. Transient drainage was modeled to determine if seepage would occur from the toe of the cell (MKF Calc. No. 06-570-12-00). Modeling results indicated the need for standpipe installation and a pumping system to remove transient drainage water. $\mathrm{A}$ temporary liner also was needed.

3. Three 18-inch (46-centimeter) diameter standpipes were constructed in the Rifle disposal cell. Two extended down to the bottom of the cell; one bottomed on a bench in the sidewall of the cell. Water levels in the standpipes were monitored. A water elevation of $6020 \mathrm{ft}$ (1835 meters [m]) was critical, as it was the elevation of the temporary liner. No water was ever observed in the bench standpipe. The other two were pumped until October 1995 and a total of 2.3 million gal (8.7 million $L)$ of transient drainage water was removed. This water was reapplied to the tailings for dust control and compaction, resulting in its evaporation.

\section{Reference:}

28. DOE (U.S. Department of Energy), 1992. Remedial Action Plan and Site Design for Stabilization of the Inactive Uranium Mill Tailings Sites at Rifle, Colorado, prepared by the U.S. Department of Energy, UMTRA Project Office, Albuquerque Operations Office, Albuquerque, New Mexico. 


\section{SALT LAKE CITY (Clive), UTAH}

- Cell type

- Cell area

- Amount of tailings in cell

- Ground water protection strategy

- Ground water remediation program

- Yearly precipitation

- Cover infiltration
Relocated

60 acres

$2,710,000$ cubic yards

Grandfathered

Not applicable

8.61 inches

1.61 inches per year

Notes: 1. Transient drainage was not modeled. Site design was completed well before the 1987 proposed ground water standards.

2. Supplemental standards could have been applied as a ground water protection strategy at Clive. Total dissolved solids were in the range of 20,000 to 50,000 $\mathrm{mg} / \mathrm{L}$. Extensive treatment of the ground water would be required for even limited industrial use. There are no identified uses of ground water in the area of the disposal cell.

\section{Reference:}

41. DOE (U.S. Department of Energy), 1984. Remedial Action and Site Conceptual Design for Stabilization of the Inactive Uranium Mill Tailings Site at Salt Lake City, Utah, final, UMTRA-DOE/AL-050502.0141, prepared by the U.S. Department of Energy, UMTRA Project Office, Albuquerque Operations Office, Albuquerque, New Mexico, December 1984. 

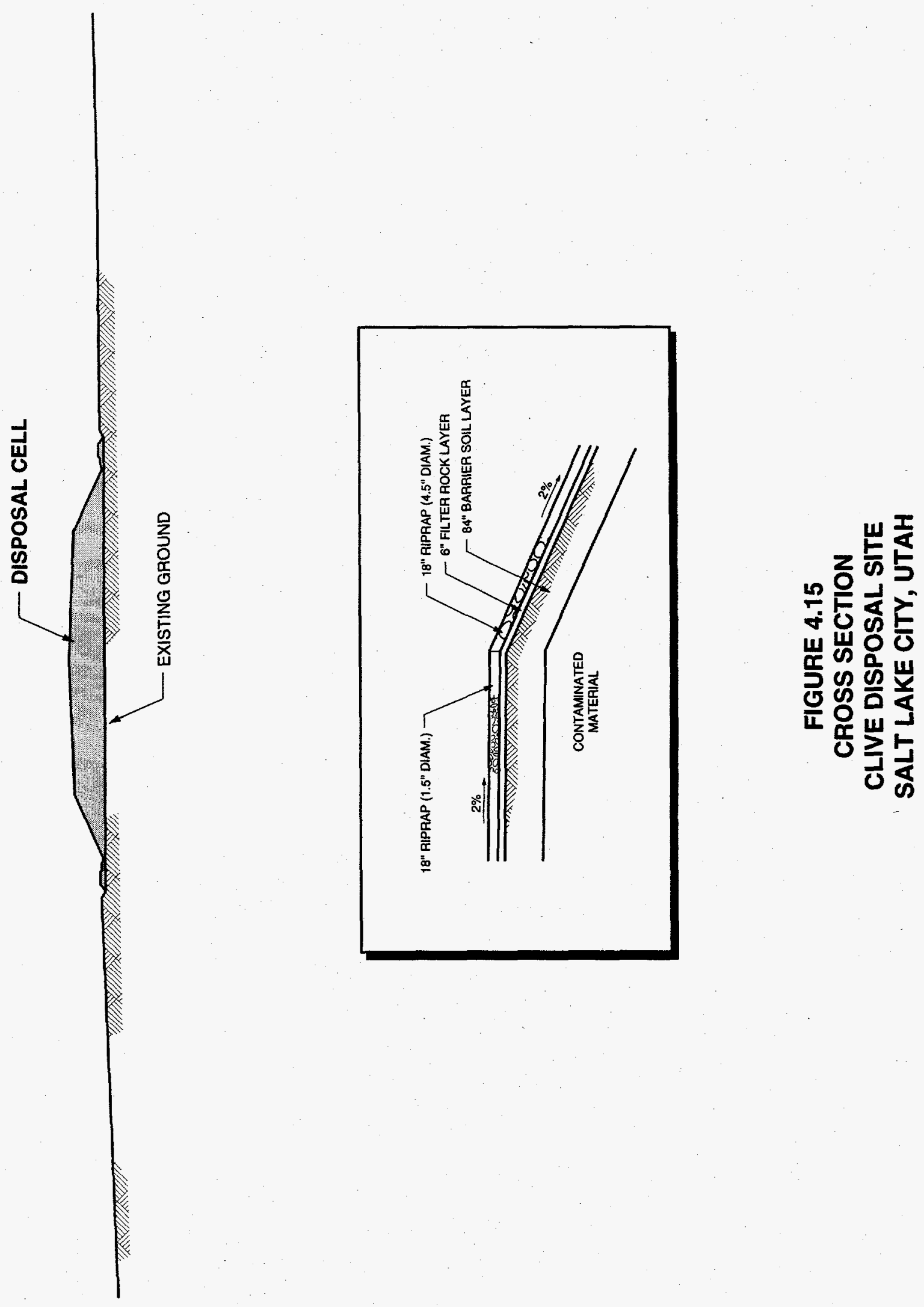


\section{SHIPROCK, NEW MEXICO}

- Cell type

- Cell area

- Amount of tailings in cell In place Relocated

- Ground water protection strategy

- Proposed ground water remediation program

- Yearly precipitation

- Cover infiltration
Stabilized in place

76 acres

$1,079,000$ cubic yards 928,000 cubic yards

Grandfathered

Gradient manipulation/passive

6.4 inches

1.24 inches per year

Note: Surface remediation was completed at this site before the 1987 ground water standards were proposed. Analysis of the cell concentrated on cover layer performance. No transient drainage modeling was performed. The NRC did not require proof of compliance with the 1987 standards.

\section{References:}

9. DOE (U.S. Department of Energy), 1995. Site Observational Work Plan for the UMTRA Project Site at Shiprock, New Mexico, DOE/AL/62350-158, Rev. 0, prepared for the U.S. Department of Energy, Environmental Restoration Division, UMTRA Project Team, Albuquerque, New Mexico.

19. DOE (U.S. Department of Energy), 1993. Long-Term Surveillance Plan for the Shiprock, New Mexico, Disposal Site, UMTRA-DOE/AL-350204.0000, U.S. Department of Energy, UMTRA Project Office, Albuquerque Operations Office, Albuquerque, New Mexico, January 1993.

40. DOE (U.S. Department of Energy), 1985. Remedial Action Plan and Site Conceptual Design for Stabilization of the Inactive Uranium Mill Tailings Site at Shiprock, New Mexico, UMTRA-DOE/AL-050504.0000, June 1985, prepared for the U.S. Department of Energy, UMTRA Project Office, Albuquerque Operations Office, Albuquerque, New Mexico. 


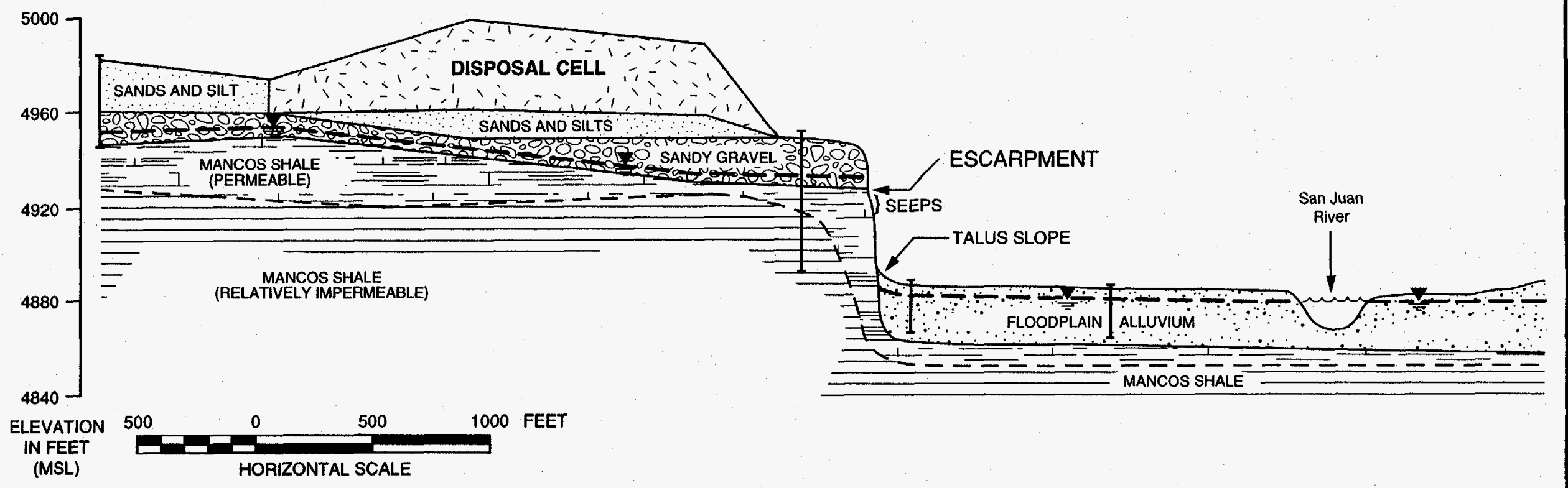

ث્ట

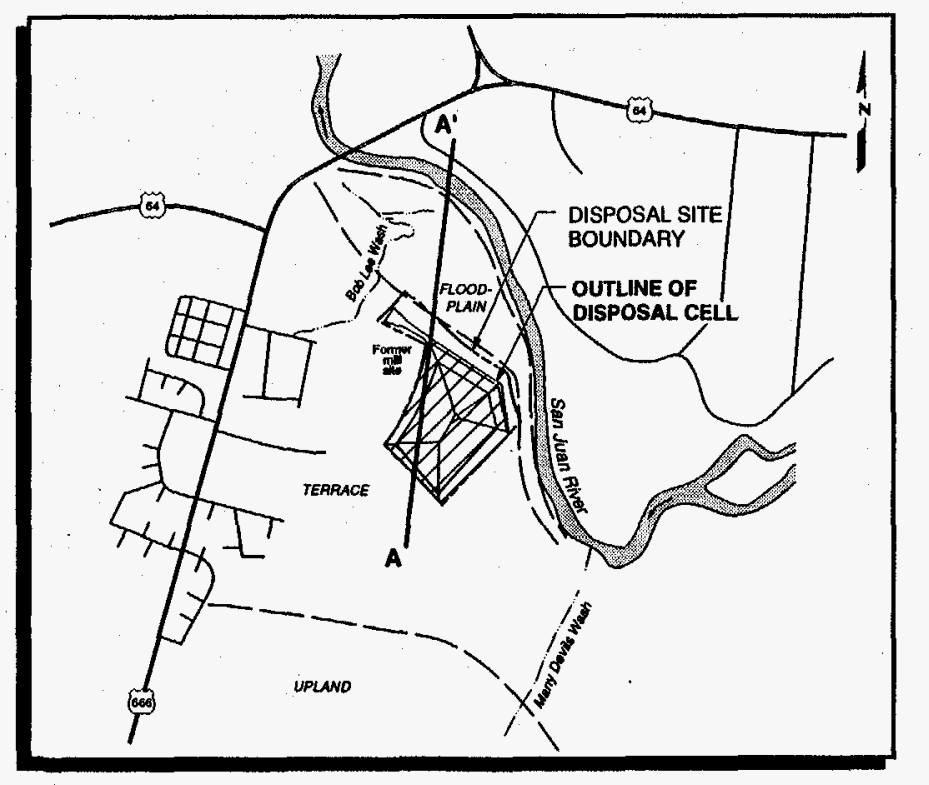

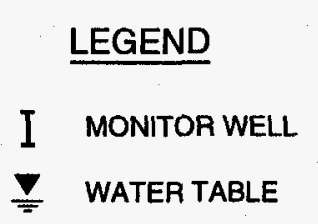

FIGURE 4.16

HYDROGEOLOGIC CROSS SECTION SHIPROCK, NEW MEXICO, SITE 


\section{SLICK ROCK (Burro Canyon), COLORADO}

- Cell type

- Cell area

- Amount of tailings in cell

- Ground water protection strategy

- Ground water remediation program

- Yearly precipitation

- Cover infiltration

\section{Relocated}

12 acres

621,000 cubic yards

Supplemental standards

Not applicable

7 inches

1.24 inches per year

Note: The supplemental standards compliance is based on the low yield of the uppermost aquifer (less than $150 \mathrm{gal}$ [ $570 \mathrm{~L}$ ] per day). There is a 50 - to $65-\mathrm{ft}(15$ to $20 \mathrm{~m}$ ) layer of low-permeability mudstone between this sandstone aquifer and the cell. Deeper aquifers are protected by additional mudstone layers and by upward vertical hydraulic gradients that inhibit downward migration of water. Low (20 percent saturation) moisture of the sand tailings that were left after the fines were taken to Rifle for reprocessing leaves little water for transient drainage.

\section{References:}

15. DOE (U.S. Department of Energy), 1994. Remedial Action Plan for Stabilization of the Inactive Uranium Mill Tailings Sites at Slick Rock, Colorado, preliminary final, DOE/AL/62350-21PF, prepared for the U.S. Department of Energy, UMTRA Project Office, Albuquerque Operations Office, Albuquerque, New Mexico.

21. DOE (U.S. Department of Energy), 1993. Remedial Action Plan and Site Design for Stabilization of the Inactive Uranium Processing Site at Slick Rock, Colorado, draft, DOE/AL/62350-21D, prepared by the U.S. Department of Energy, UMTRA Project Office, Albuquerque Operations Office, Albuquerque, New Mexico, July 1993. 


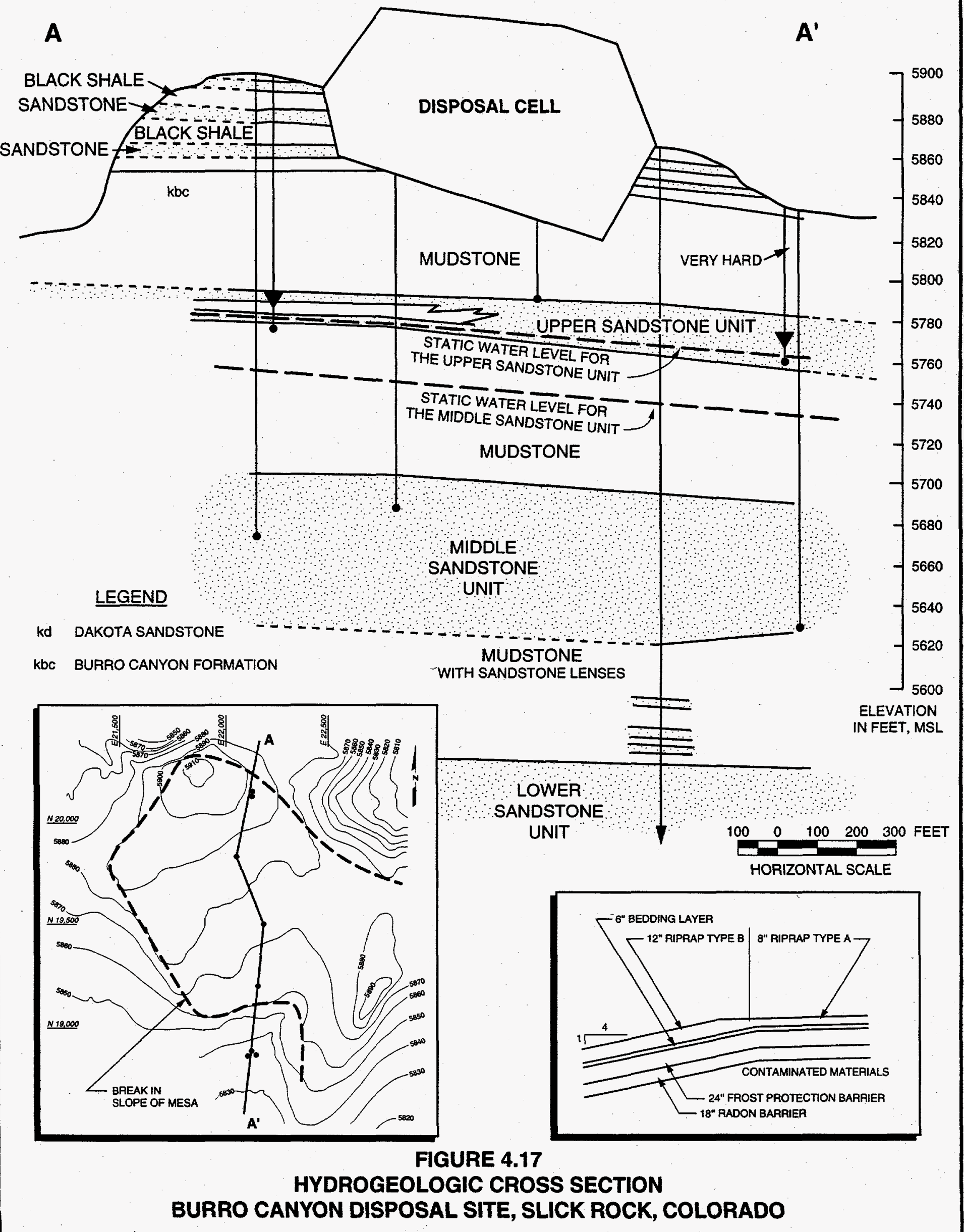




\section{SPOOK, WYOMING}

- Cell type

- Cell area

- Amount of tailings in cell

- Ground water protection strategy

- Ground water remediation program

- Yearly precipitation

- Cover infiltration
Stabilized in place

13.5 acres

314,000 cubic yards

Supplemental standards

No further action

11.22 inches

0.37 inches per year

Notes: 1 . Supplemental standards compliance was based on limited use water in the uppermost aquifer due to widespread, ambient contamination from natural sources.

2. The rate of transient drainage was estimated to be less than the steady-state infiltration rate; therefore little impact from transient drainage is expected.

\section{References:}

10. DOE (U.S. Department of Energy), 1995. Site Observational Work Plan for the UMTRA Project Site at Spook, Wyoming, DOE/AL/62350-156, Rev. 0, May 1995, prepared for the U.S. Department of Energy, UMTRA Project Office, Albuquerque, New Mexico.

20. DOE (U.S. Department of Energy), 1993. Long-Term Surveillance Plan for the Spook, Wyoming, Disposal Site, final, UMTRA-DOE/AL-350215.0000, U.S. Department of Energy, UMTRA Project Office, Albuquerque Operations Office, Albuquerque, New Mexico, January 1993.

34. DOE (U.S. Department of Energy), 1990. Remedial Action Plan and Site Design for Stabilization of the Inactive Uranium Mill Tailings at the Spook Site, Converse County, Wyoming, UMTRA-DOE/AL-050515.0000, DOE UMTRA Project Office, Albuquerque Operations Office, Albuquerque, New Mexico. 


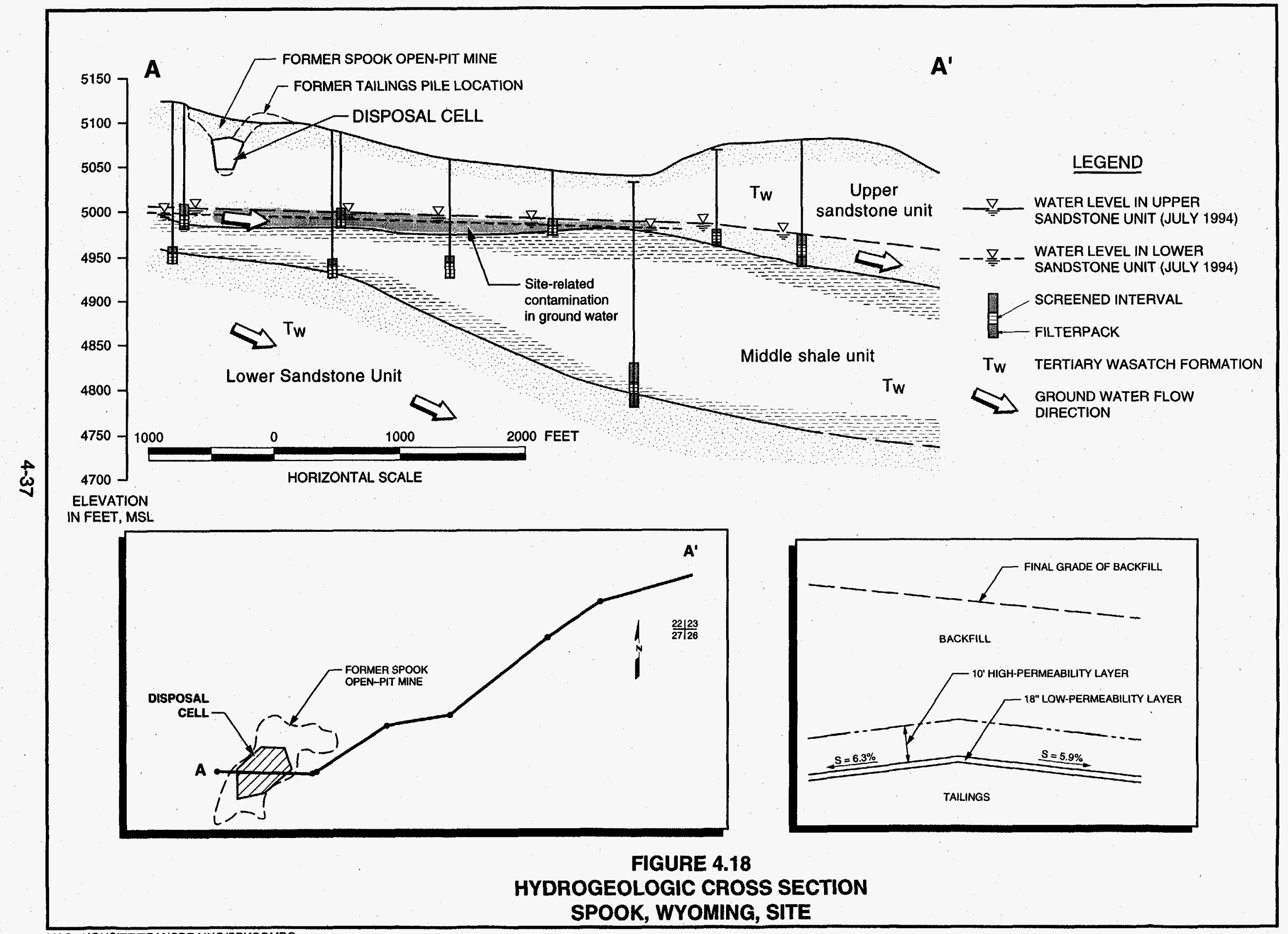




\section{TUBA CITY, ARIZONA}

- Cell type

- Cell area

- Amount of tailings in cell In place Relocated

- Ground water protection strategy

- Proposed ground water remediation program

- Yearly precipitation

- Cover infiltration
Stabilized in place

50 acres

$1,400,000$ cubic yards 230,500 cubic yards

Maximum concentration limits

To be determined

6.2 inches

0.12 inches per year

Note: Transient drainage was modeled after cell construction to help evaluate cell performance. The initial modeling was only of the transient drainage. The modeling showed a relatively small amount of water leaving the cell.

After extreme storm events in 1994, monitor wells east of the disposal cell were observed to have increased water levels and increased contaminant levels. The timing of these increases coincided with the time predicted for the transient drainage to reach the wells. Additional modeling indicates that the increases in water levels and contaminants are a result of the runoff and infiltration of precipitation, not transient drainage (Calc. No. TUB-11-95-11-01-00).

Regardless of the source of the contaminated water, action is being taken. Extraction wells have been installed along the east side of the cell, and water will be pumped out and treated to remove metals and nitrates. The resulting water will be high in sulfates, but may be used for irrigation at the adjacent soil stabilization project.

\section{References:}

11. DOE (U.S. Department of Energy), 1995. Site Observational Work Plan for the UMTRA Project Site at Tuba City, Arizona, DOE/AL/62350-161, Rev. 0, July 1995, prepared for the U.S. Department of Energy, UMTRA Project Office, Albuquerque, New Mexico.

24. DOE (U.S. Department of Energy), 1992. Long-Term Surveillance Plan for the Tuba City, Arizona, Disposal Site, final, UMTRA-DOE/AL-350218.0000, DOE UMTRA Project

Office, Albuquerque Operations Office, Albuquerque, New Mexico, December 1992.

35. DOE (U.S. Department of Energy), 1989. Remedial Action Plan and Site Conceptual Design for Stabilization of the Inactive Uranium Mill Tailings Site at Tuba City, Arizona, UMTRA-DOE/AL-050518.0000, final, DOE UMTRA Project Office, Albuquerque Operations Office, Albuquerque, New Mexico, August 1989. 


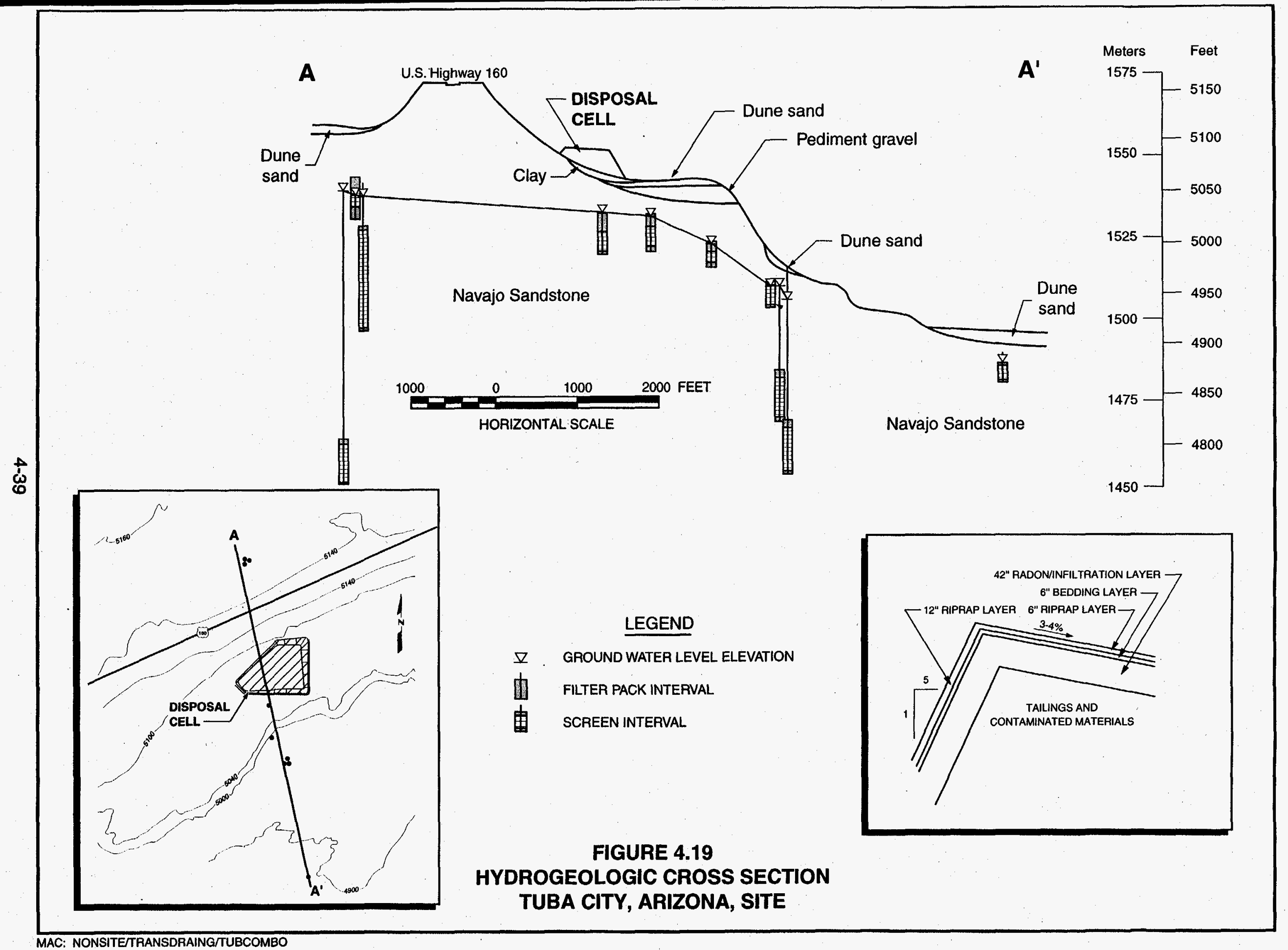




\subsection{CONCLUSIONS}

Transient drainage is an issue for the UMTRA Project for the reasons discussed in this report: 1) geotechnical stability, 2) water resources protection, 3) disposal cell performance monitoring, and 4) its continuation as a source term that affects the ground water program. At many disposal sites transient drainage has not been quantified because the ground water quality already does not meet the standards due to widespread, ambient contamination from natural sources. UMTRA Project efforts to limit transient drainage include the design and construction changes below:

- Minimizing the addition of construction water by using misting attachments on water trucks, changing specifications to require compaction of tailings in a relatively dry condition, adding additional requirements for quality control to ensure dry conditions are met, and using surfactants instead of water to control dust.

- Using low-permeability winter covers to limit infiltration into tailings materials prior to final cover placement.

- Installing special mechanisms to remove transient drainage water as needed, such as at the Rifle site.

- Limiting infiltration through the final cover by increasing runoff and drainage and decreasing radon barrier permeability so that excessive cover infiltration will not mingle with the transient drainage water.

It should also be understood that the locations of the UMTRA Project disposal cells were chosen carefully to mitigate future problems with the ground water to the extent possible. This included locating the cells away from heavily used, high-quality aquifers and surface water when possible. The UMTRA Project will continue to monitor the disposal sites to ensure that transient drainage effects are not detrimental to the environment. 


\subsection{LIST OF CONTRIBUTORS}

The following individuals contributed to the preparation of this report.

\begin{tabular}{ll}
\hline Name & Contribution \\
\hline J. Lommler & Document sponsor \\
B. Bridgeman & Primary author \\
A. Holm & Document review \\
J. Torline, D. Kahl & Editing \\
S. Portlock, L. Sanchez & Text processing \\
\hline
\end{tabular}




\subsection{BIBLIOGRAPHY}

1. DOE (U.S. Department of Energy), 1996. Long-Term Surveillance Plan for the Mexican Hat Disposal Site, Mexican Hat, Utah, DOE/AL62350-207, Rev. 1, February 1996, prepared for the U.S. Department of Energy, Environmental Restoration Division, UMTRA Project Team, Albuquerque, New Mexico.

2. DOE (U.S. Department of Energy), 1996. Site Observational Work Plan for the UMTRA Project Site at Grand Junction, Colorado, DOE/AL/62350-215, Rev. 0, January 1996, prepared for the U.S. Department of Energy, Grand Junction Projects Office, Grand Junction, Colorado.

3. DOE (U.S. Department of Energy), 1995. Long-Term Surveillance Plan for the Ambrosia Lake, New Mexico, Disposal Site, DOE/AL/62350-211, Rev. 0, November 1995, prepared for the U.S. Department of Energy, UMTRA Project Team, Albuquerque Operations Office, Albuquerque, New Mexico.

4. DOE (U.S. Department of Energy), 1995. Long-Term Surveillance Plan for the Canonsburg, Pennsylvania, Disposal Site, DOE/AL/62350-203, Rev. 0, October 1995, prepared for the U.S. Department of Energy, UMTRA Project Team, Albuquerque Operations Office, Albuquerque, New Mexico.

5. DOE (U.S. Department of Energy), 1995. Long-Term Surveillance Plan for the Bodo Canyon Disposal Site, Durango, Colorado, DOE/AL/62350-77, Rev. 1, Ver. 4, November 1995, prepared for the U.S. Department of Energy, UMTRA Project Team, Albuquerque Operations Office, Albuquerque, New Mexico.

6. DOE (U.S. Department of Energy), 1995. Long-Term Surveillance Plan for the Falls City Disposal Site, Falls City, Texas, DOE/AL/62350-187, Rev. 1, June 1995, prepared for the U.S. Department of Energy, UMTRA Project Office, Albuquerque Operations Office, Albuquerque, New Mexico.

7. DOE (U.S. Department of Energy), 1995. Site Observational Work Plan for the UMTRA Project Site at Ambrosia Lake, New Mexico, Rev. 0, UMTRA-DOE/AL-62350-159, prepared for the U.S. Department of Energy, UMTRA Project Office, Albuquerque Operations Office, Albuquerque, New Mexico.

8. DOE (U.S. Department of Energy), 1995. Site Observational Work Plan for the UMTRA Project Site at Falls City, Texas, DOE/AL/62350-157, Rev. 0, June 1995, prepared for the U.S. Department of Energy, UMTRA Project Office, Albuquerque Operations Office, Albuquerque, New Mexico.

9. DOE (U.S. Department of Energy), 1995. Site Observational Work Plan for the UMTRA Project Site at Shiprock, New Mexico, DOE/AL/62350-158, Rev. 0, prepared for the U.S. Department of Energy, Environmental Restoration Division, UMTRA Project Team, Albuquerque, New Mexico. 
10. DOE (U.S. Department of Energy), 1995. Site Observational Work Plan for the UMTRA Project Site at Spook, Wyoming, DOE/AL/62350-156, Rev. 0, May 1995, prepared for the U.S. Department of Energy, UMTRA Project Office, Albuquerque, New Mexico.

11. DOE (U.S. Department of Energy), 1995. Site Observational Work Plan for the UMTRA Project Site at Tuba City, Arizona, DOE/AL/62350-161, Rev. 0, July 1995, prepared for the U.S. Department of Energy, UMTRA Project Office, Albuquerque, New Mexico.

12. DOE (U.S. Department of Energy), 1995. UMTRA Project Site Observational Work Plan, Mexican Hat, Utah, DOE/AL/62350-153, Rev. 0, September 1995, prepared for the U.S. Department of Energy, Environmental Restoration Division, UMTRA Project Team, Albuquerque, New Mexico.

13. DOE (U.S. Department of Energy), 1994. Long-Term Surveillance Plan for the Green River, Utah, Disposal Site, DOE/AL/62350-89F, Rev. 1, August 1994, prepared for the U.S. Department of Energy, UMTRA Project Office, Albuquerque Operations Office, Albuquerque Operations Office, Albuquerque, New Mexico.

14. DOE (U.S. Department of Energy), 1994. Remedial Action Plan for the Inactive Uranium Processing Site at Naturita Colorado, DOE/AL/62350-142, Rev. 0, prepared for the U.S. Department of Energy, UMTRA Project Office, Albuquerque Operations Office, Albuquerque, New Mexico.

15. DOE (U.S. Department of Energy), 1994. Remedial Action Plan for Stabilization of the Inactive Uranium Mill Tailings Sites at Slick Rock, Colorado, preliminary final, DOE/AL/62350-21PF, prepared for the U.S. Department of Energy, UMTRA Project Office, Albuquerque Operations Office, Albuquerque, New Mexico.

16. DOE (U.S. Department of Energy), 1994. Remedial Action Plan and Site Design for Stabilization of the Inactive Mill Tailings Site, Maybell, Colorado, DOE/AL-6235024F, June 1994, prepared for the U.S. Department of Energy, UMTRA Project Office, Albuquerque Operations Office, Albuquerque, New Mexico.

17. DOE (U.S. Department of Energy), 1993. Burrell, Pennsylvania, Vicinity Property LongTerm Surveillance Plan, final, DOE/AL-62350-3F, prepared by the U.S. Department of Energy, UMTRA Project Office, Albuquerque Operations Office, Albuquerque, New Mexico, September 1993.

18. DOE (U.S. Department of Energy), 1993. Long-Term Surveillance Plan for the Lowman, Idaho, Disposal Site, preliminary final, DOE/AL/62350-36PF, U.S. Department of Energy, UMTRA Project Office, Albuquerque Operations Office, Albuquerque, New Mexico, September 1993. 
19. DOE (U.S. Department of Energy), 1993. Long-Term Surveillance Plan for the Shiprock, New Mexico, Disposal Site, UMTRA-DOE/AL-350204.0000, U.S. Department of Energy, UMTRA Project Office, Albuquerque Operations Office, Albuquerque, New Mexico, January 1993.

20. DOE (U.S. Department of Energy), 1993. Long-Term Surveillance Plan for the Spook, Wyoming, Disposal Site, final, UMTRA-DOEJAL-350215.0000, U.S. Department of Energy, UMTRA Project Office, Albuquerque Operations Office, Albuquerque, New Mexico, January 1993.

21. DOE (U.S. Department of Energy), 1993. Remedial Action Plan and Site Design for Stabilization of the Inactive Uranium Processing Site at Slick Rock, Colorado, draft, DOE/AL/62350-21D, prepared by the U.S. Department of Energy, UMTRA Project Office, Albuquerque Operations Office, Albuquerque, New Mexico, July 1993.

22. DOE (U.S. Department of Energy), 1993. Remedial Action Plan for the Codisposal and Stabilization of the Monument Valley and Mexican Hat Uranium Mill Tailings at Mexican Hat, Utah, final, UMTRA-DOE/AL 050509.0000, prepared by the U.S. Department of Energy, UMTRA Project Office, Albuquerque Operations Office, Albuquerque, New Mexico, February 1993.

23. DOE (U.S. Department of Energy), 1992. Long-Term Surveillance and Maintenance Plan for the Lakeview, Oregon, Disposal Site, final, UMTRA-DOE/AL-350213.0000, DOE UMTRA Project Office, Albuquerque Operations Office, Albuquerque, New Mexico, September 1992.

24. DOE (U.S. Department of Energy), 1992. Long-Term Surveillance Plan for the Tuba City, Arizona, Disposal Site, final, UMTRA-DOE/AL-350218.0000, DOE UMTRA Project Office, Albuquerque Operations Office, Albuquerque, New Mexico, December 1992.

25. DOE (U.S. Department of Energy), 1992. Remedial Action Plan and Site Design for Stabilization of the Inactive Uranium Mill Tailings Site at Falls City, Texas, final, DOE/AL-050520.0000, DOE UMTRA Project Office, Albuquerque Operations Office, Albuquerque, New Mexico, September 1992.

26. DOE (U.S. Department of Energy), 1992. Remedial Action Plan and Site Design for Stabilization of the Inactive Uranium Mill Tailings Site at Gunnison, Colorado, final, DOE/AL-050508.0000, DOE UMTRA Project Office, Albuquerque Operations Office, Albuquerque, New Mexico, October 1992.

27. DOE (U.S. Department of Energy), 1992. Remedial Action Plan and Site Design for Stabilization of the Inactive Uranium Mill Tailings Site at Lakeview, Oregon, final, DOE/AL-050510.0000, Rev. 1, DOE UMTRA Project Office, Albuquerque Operations Office, Albuquerque, New Mexico, July 1992.

28. DOE (U.S. Department of Energy), 1992. Remedial Action Plan and Site Design for Stabilization of the Inactive Uranium Mill Tailings Sites at Rifle, Colorado, prepared by the U.S. Department of Energy, UMTRA Project Office, Albuquerque Operations Office, Albuquerque, New Mexico. 
29. DOE (U.S. Department of Energy), 1991. Remedial Action Plan and Site Design for Stabilization of the Inactive Uranium Mill Tailings at Ambrosia Lake, New Mexico, final, UMTRA-DOE/AL-050516.0000, DOE UMTRA Project Office, Albuquerque Operations Office, Albuquerque, New Mexico, February 1991.

30. DOE (U.S. Department of Energy), 1991. Remedial Action Plan and Site Design for Stabilization of the Inactive Uranium Mill Tailings at Durango, Colorado, revised final, UMTRA-DOE/AL-050503.0000, DOE UMTRA Project Office, Albuquerque Operations Office, Albuquerque, New Mexico, December 1991.

31. DOE (U.S. Department of Energy), 1991. Remedial Action Plan and Final Design for Stabilization of the Inactive Uranium Mill Tailings at Grand Junction, Colorado, final, UMTRA-DOE/AL-050505.0000, DOE UMTRA Project Office, Albuquerque Operations Office, Albuquerque, New Mexico, September 1991.

32. DOE (U.S. Department of Energy), 1991. Remedial Action Plan and Final Design for Stabilization of the Inactive Uranium Mill Tailings at Green River, Utah, final, UMTRA-DOE/AL-050510.GRNO, DOE UMTRA Project Office, Albuquerque Operations Office, Albuquerque, New Mexico, March 1991.

33. DOE (U.S. Department of Energy), 1991. Remedial Action Plan and Site Design for Stabilization of the Inactive Uranium Mill Tailings at the Lowman Site, Lowman, Idaho, UMTRA-DOE/AL-050512.0000, September 1991, prepared by the U.S. Department of Energy, UMTRA Project Office, Albuquerque Operations Office, Albuquerque, New Mexico.

34. DOE (U.S. Department of Energy), 1990. Remedial Action Plan and Site Design for Stabilization of the Inactive Uranium Mill Tailings at the Spook Site, Converse County, Wyoming, UMTRA-DOE/AL-050515.0000, DOE UMTRA Project Office, Albuquerque Operations Office, Albuquerque, New Mexico.

35. DOE (U.S. Department of Energy), 1989. Remedial Action Plan and Site Conceptual Design for Stabilization of the Inactive Uranium Mill Tailings Site at Tuba City, Arizona, UMTRA-DOE/AL-050518.0000, final, DOE UMTRA Project Office, Albuquerque Operations Office, Albuquerque, New Mexico, August 1989.

36. DOE (U.S. Department of Energy), 1989. Technical Approach Document, UMTRADOE/AL-050425.0002, prepared for the U.S. Department of Energy, UMTRA Project Office, Albuquerque Operations Office, Albuquerque, New Mexico. 
37. DOE (U.S. Department of Energy), 1988. Remedial Action Plan and Site Design for Stabilization of the Inactive Uranium Mill Tailings Site at Mexican Hat, Utah, UMTRA-DOE/AL-050509.0000, prepared by the U.S. Department of Energy, UMTRA Project Office, Albuquerque Operations Office, Albuquerque, New Mexico.

38. DOE (U.S. Department of Energy), 1986. Remedial Action Plan and Site Conceptual Design for Stabilization of the Inactive Uranium Mill Tailings Site at Monument Valley, Arizona, unpublished draft, prepared by the U.S. Department of Energy, UMTRA Project Office, Albuquerque Operations Office, Albuquerque, New Mexico.

39. DOE (U.S. Department of Energy), 1986. Technical Approach Document, UMTRADOE/AL-050425, prepared for the U.S. Department of Energy, UMTRA Project Office, Albuquerque Operations Office, Albuquerque, New Mexico.

40. DOE (U.S. Department of Energy), 1985. Remedial Action Plan and Site Conceptual Design for Stabilization of the Inactive Uranium Mill Tailings Site at Shiprock, New Mexico, UMTRA-DOE/AL-050504.0000, June 1985, prepared for the U.S. Department of Energy, UMTRA Project Office, Albuquerque Operations Office, Albuquerque, New Mexico.

41. DOE (U.S. Department of Energy), 1984. Remedial Action and Site Conceptual Design for Stabilization of the Inactive Uranium Mill Tailings Site at Salt Lake City, Utah, final, UMTRA-DOE/AL-050502.0141, prepared by the U.S. Department of Energy, UMTRA Project Office, Albuquerque Operations Office, Albuquerque, New Mexico, December 1984.

42. DOE (U.S. Department of Energy), 1983. Remedial Action Plan for Stabilization of the Inactive Uranium Mill Tailings Site at Canonsburg, Pennsylvania, UMTRA-DOE/AL140, prepared for the U.S. Department of Energy, UMTRA Project Office, Albuquerque Operations Office, Albuquerque, New Mexico.

43. NRC (U.S. Nuclear Regulatory Commission), 1983. In Situ Dewatering Techniques for Uranium Mill Tailings, NUREG/CR-3203, U.S. Nuclear Regulatory Commission, Office of Nuclear Material and Safeguards.

44. Bergin, M.J., 1959. Preliminary Geologic Map of the Maybell-Lay Area, Moffat County, Colorado, U.S. Geological Survey Open File Report.

45. 42 USC $\$ 7901$ et seq., Uranium Mill Tailings Radiation Control Act, 8 November 1978.

46. 40 CFR Part 192, Health and Environmental Protection Standards for Uranium and Thorium Mill Tailings, U.S. Environmental Protection Agency.

47. Durango-Bodo Canyon Toe Drain Study Report (Draft) and Supporting Documentation, UPDCC Remote Box No. 978, Albuquerque, New Mexico. 